\title{
Kegagalan Implementasi REDD+ Ulu Masen Aceh
}

\author{
Andrea Prisca \\ Jurusan lmu Hubungan Internasional, International University Liaison Indonesia \\ Email: kurnadi.andrea@gmail.com
}

\begin{abstract}
Abstrak
Artikel ini membahas kegagalan implementasi REDD+ Ulu Masen di Aceh pada periode 2007-2012. Kegagalan yang dimaksudkan adalah tidak berjalannya implementasi progam REDD+ serta tidak tercapainya target yang telah disusun. Implementasi program REDD+ mengacu pada multi-level governance yang mengharuskan terjalinnya kemitraan lintas sektor dari level internasional ke nasional, internasional ke subnasional, nasional ke sub-nasional dan vice versa. Selain itu, harus terdapat sinergitas serta koordinasi antar aktor pada masing-masing level agar tujuan kolektif yang disusun tercapai. Penelitian ini adalah penelitian kualitatif dengan desain deskriptif. Hasil penelitian menemukan bahwa kegagalan implementasi REDD+ Ulu Masen disebabkan kemitraan lintas sektor tidak terjalin antara level satu dengan lainnya, serta adanya benturan kepentingan di antara aktor pada masing-masing level.
\end{abstract}

Kata Kunci: koordinasi; multi-level governance, kemitraan lintas sektor; sinergi; REDD+

\begin{abstract}
The article explains the failure of REDD+ implementation in Ulu Masen, Aceh from 2007-2012. The aforementioned failure has been characterized by the unsuccessful implementation of REDD+ framework and failure to accomplish the designated targets. REDD+ implementation framework is identified with multi-level governance mechanism which requires the presence of cross-sector partnership from international to national level, international to sub-national level, national to sub-national level and vice versa. It is fundamental for each actors in each level to synergize and coordinate each actions in order to achieve the collective purposes of designated targets. This research is conducted by qualitative method and uses descriptive design. The research discovers that the failure of REDD+ implementation is caused by the absence of cross-sector partnership and the conflict of interests between actors in every level.
\end{abstract}

Keywords: coordination; multi-level governance; cross-sector partnership; synergy; REDD+

\section{Pendahuluan}

Lebih dari dua dekade berlalu setelah berlangsungnya Konferensi Rio, di mana komunitas internasional berdiskusi dan berusaha mencari jalan keluar dari permasalahan lingkungan yang semakin parah. Permasalahan-permasalahan lingkungan seperti perubahan iklim, deforestasi, polusi udara, polusi air, kerusakan biodiversitas laut dan masih banyak lainnya, memerlukan penanganan

bersama dalam skala global mengingat saling terhubungnya keadaan ekologi bumi. ${ }^{1}$

Permasalahan lingkungan dalam skala global pada akhirnya memaksa negara menyadari bahwa mereka tidak

\footnotetext{
${ }^{1}$ Esty, Daniel and Maria Ivanova, 2002, Revitalising Global Environmental Governance: A Function-Driven Approach, dalam Daniel Esty and Maria Ivanova (eds), 2002, Global Environmental Governance: Options and Opportunities, Yale School of Forestry and Enviromental Studies, hlm 1
} 
dapat mengatasinya sendirian, mereka harus bekerjasama dengan aktor nonnegara baik Non-Governmental Organizations (NGOs), perusahaan multinasional hingga individu. Interaksi di antara mereka ini kemudian yang melahirkan sebuah bentuk tata kelola atau rezim lingkungan yang dimaksudkan untuk mensinkronisasi kebijakan-kebijakan mengatasi permasalahan-permasalahan tersebut. $^{2}$

Dengan demikian, kelola atau rezim lingkungan diatur dalam perjanjianperjanjian multilateral yang disepakati bersama oleh negara. Pada akhirnya, tata kelola berfungsi tidak hanya mensinkronisasi kebijakan, tetapi juga sebagai sebuah mekanisme yang meliputi organisasi, instrumen kebijakan, mekanisme pendanaan, aturan, prosedur dan norma-norma yang meregulasi proses perlindungan lingkungan global. ${ }^{3}$ United Nations Environmental Programme (UNEP) menyatakan bahwa hingga Desember tahun 2009, tercatat sekitar 290 perjanjian multilateral yang diarahkan khusus mengatasi permasalahan lingkungan. ${ }^{4}$ Perjanjian ini dapat berbentuk

\footnotetext{
2 Risse, Thomas, 2011, Governance without a state? policies and politics in areas of limited statehood,. New York: Columbia University Press ${ }^{3}$ Najam, Adil, Mihaela Papa, and Nadaa Taiyab, 2006, Global Environmental Governance: A Reform Agenda, Denmark: International Institute for Sustainable Development, hlm 3 ${ }^{4}$ http://www.unep.org/delc/Portals/119/audingmeas. pdf hlm 4
}

pakta, persetujuan, piagam, protokol, atau bahkan konstitusi. $^{5}$

Sayangnya, tata kelola lingkungan global terkesan hanya menjadi sebuah gerakan tanpa ada perkembangan dan hasil yang nyata. Mekanisme tata kelola lingkungan global dianggap tidak efektif, lemah, fragmented. ${ }^{6}$ Dalam sistem tata kelola lingkungan global terjadi gap institusional dimana terdapat gap yurisdiksi, gap informasi dan gap implementasi. ${ }^{7}$

Situasi ini mendorong suatu pemikiran bahwa tata kelola lingkungan global membutuhkan bentuk mekanisme baru yang lebih efektif. Dalam beberapa tahun terakhir, mekanisme tata kelola

\footnotetext{
${ }^{5}$ Ibid

${ }^{6}$ Esty, Daniel and Maria Ivanova, Op.Cit., hlm 2

${ }^{7}$ Gap yurisdiksi disebabkan oleh kesenjangan antara permasalahan lingkungan yang sifatnya lintas batas teritori dengan dominannya kekuasaan pemerintah nasional dalam pembuatan kebijakan. Rezim tidak memiliki kapasitas otoritatif untuk memaksakan aturan rezim dan negara tidak menyadari peranan mereka dalam upaya mengatasi masalah lingkungan global. Selain itu, ada pula gap informasi, yakni dalam bidang lingkungan di mana permasalahan tersebar pada tempat dan waktu yang beragam, maka informasi mengenai masalah lingkungan beserta kecenderungan, tren, pilihan kebijakan, hasil, kepatuhan pelaksanaan sesuai dengan komitmen dari berbagai negara menjadi penting. Dengan adanya hal-hal tersebut, akan memudahkan adanya penilaian, verifikasi dan analisis yang berguna bagi pembuatan keputusan atau tindakan di masa depan. Hambatan utama bagi kemajuan lingkungan dalam skala global adalah adanya gap implementasi, ketika terlalu banyak aturan lingkungan yang mengakibatkan tiadanya orientasi tindakan. Banyaknya aturan menyebabkan skala nasional dimana kemampuan politik, ekonomi, administrasi untuk mengimplentasi aturan berada justru terbebani. Lihat di ibid, hlm 3-8
} 
lingkungan dengan sistem Multi-Level Governance (MLG) menjadi salah satu pilihan inovatif untuk mengatasi permasalahan lingkungan global.

MLG didefinisikan sebagai "supranational, national, regional and local governments are enmeshed in territorially overarching policy networks". ${ }^{8}$ Oleh karenanya, konsep MLG berdimensi vertical maupun horizontal. Multi-level merujuk pada peningkatan interdependensi antara pemerintah yang beroperasi pada tingkatan yang berbedabeda, sedangkan governance menunjukkan pertumbuhan interdependensi antara pemerintah dan aktor-aktor nonpemerintah dalam berbagai level teritorial. Dalam hal ini, MLG menitikberatkan pada interaksi antara negara dan non-negara yang lebih luas dan fleksibel, bukan sekedar hubungan top-down dan commandcontrol yang sangat state-centric.

Menurut Bache and Flinders, untuk memahami MLG maka harus memahami konsep dan bentuk intergovernmentalisme. Pertama, MLG bukan bentuk intergovernmentalisme tradisional di mana hanya berfokus pada aktor publik (pemerintah). Dalam MLG, aktor nonpublik (privat, non-pemerintah) sama-sama

\footnotetext{
8 Marks, Gary, 1993, Structural Policy and Multilevel Governance in the EU, dalam A. Cafruny and G. Rosenthal (eds.), The State of the European Community, New York: Lynne Rienner, hlm 402-403
}

terlibat dalam tata kelola. Aktor non-publik ini terdiri atas berbagai macam jenis aktor, mulai dari sektor bisnis, NGO, kelompok penekan dan lainnya. Di dalamnya, aktor publik dan privat ini memiliki sasaran masing-masing dan tujuan kolektif. Keberagaman aktor yang terlibat dalam tata kelola cenderung menciptakan multiple linkages antara proses-proses tata kelola pada level yang berbeda, yang disebut dengan kemitraan lintas sektor. ${ }^{9}$

Kedua, MLG bukanlah tatanan hirarki dalam sebuah proses tata kelola. MLG justru melihat bahwa institusiinstitusi transnasional mencoba mengikutsertakan dan berkomunikasi secara langsung dengan aktor-aktor subnasional, dan vice versa. Dalam MLG tercipta pertukaran institusional yang sifatnya ad-hoc dan dibentuk secara spesifik untuk mengatasi suatu permasalahan spesifik. Rezim (aktor transnasional) bebas memilih level mana yang menjadi sasaran kebijakan, tergantung pada keadaan alamiah masalah yang terjadi. Pemerintah nasional harus mampu memastikan bahwa kebijakan, aturan dan program yang dijalankan oleh level sub-nasional sinergi dengan aturan rezim.

\footnotetext{
${ }^{9}$ Fairbrass, Jenny and Jordan, Andrew, 2005, Multilevel governance and environmental policy, dalam Ian Bache and Matthew Flinders (eds), Multi-level governance, New York: Oxford University Press, bab 9
} 
Tata kelola yang berhasil dan

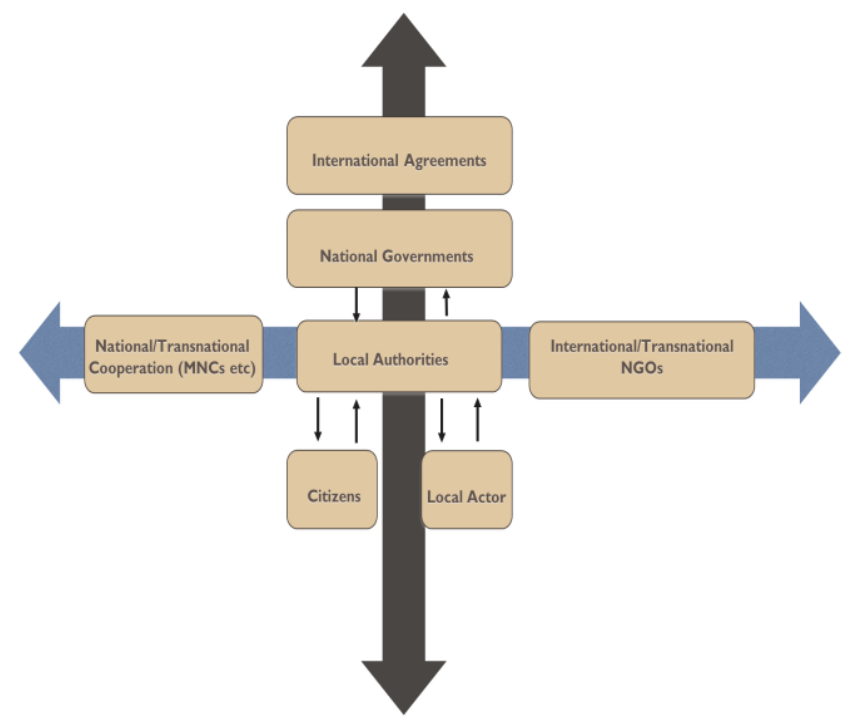

Gambar: Ilustrasi MLG

Sumber: Olahan Penulis

Terdapat 3 (tiga) komponen penting dalam MLG, yaitu pelaku, skala dan kepentingan. ${ }^{10}$. Pelaku memiliki sasaransasaran yang berbeda dan tingkat pengaruh politik yang berlainan saling terkait oleh garis hubungan horizontal. Para pelaku dapat berasal dari sektor yang berbeda, dari aktor pemerintah, swasta, investor, NGO hingga masyarakat lokal. Skala mengacu pada kaitan-kaitan vertikal antara para pelaku di tingkat nasional dan sub-nasional sesuai dengan kerangka rezim atau kebijakan organisasi transnasional.

10 Forsyth, Tim, 2009, Multilevel, multiactor governance in REDD+, dalam Arild Angelsen, M. Brockhaus, M. Kanninen, E. Sills, W. D. Sunderlin and S. Wertz-Kanounnikoff (eds), 2009, Realising REDD+: National Strategy and Policy Options, Bogor, Indonesia: Center for International Forestry Research, hlm 113-122 inklusif dapat memaksimalkan kesetaraan dan keefektifan dengan memastikan kesediaan para pelaku yang berbeda pada skala-skala yang berlainan untuk berpartisipasi. Kepentingan mengacu pada para pelaku yang memiliki kepentingan yang berbeda memiliki pemahaman yang sama akan sasaran atau target yang hendak dicapai (tujuan kolektif). Disini para pelaku yang berbeda kepentingan bersedia menerima kerangka yang dibuat oleh rezim guna mencapai tujuan kolektif yang telah ditetapkan

Tata kelola lingkungan yang menerapkan mekanisme MLG adalah manajemen kehutanan global dalam usaha mengurangi emisi gas yang menjadi penyebab perubahan iklim, yaitu Reducing Emission from Deforestation and Degradation (REDD). REDD merupakan mekanisme yang bertujuan mengurangi emisi karbon melalui pemberian insentif kepada negara-negara atau pihak yang melakukan pencegahan deforestasi dan degradasi hutan. Caranya adalah pengurangan emisi melalui konservasi hutan atau menghindari deforestasi diperhitungkan sebagai kredit yang dapat diperjual-belikan di pasar karbon. ${ }^{11}$ Kredit yang didapat akan ditukarkan melalui

11 Greenpeace (September 29, 2010). Apa itu REDD?. $\quad$ April, 2015. http://www.greenpeace.org/seasia/id/campaigns/mel indungi-hutan-alam-terakhir/apa-itu-REDD/ 
lembaga pendanaan yang sudah dibentuk untuk menyediakan kompensasi finansial bagi negara yang melakukan konservasi tersebut.

Konsep dan mekanisme REDD sendiri mengalami perubahan menjadi REDD+ (REDD plus). Perubahan ini disebabkan oleh perluasan cakupan pengertian. Pada awalnya REDD hanya mengurus masalah pengurangan emisi dari deforestasi dan degradasi hutan. Dalam REDD+ ditambahkan ketetapan lain yaitu masalah cadangan karbon hutan. Mekanisme REDD+ juga memperhatikan pelaksanaan program konservasi hutan dan manajemen hutan pada tingkat global, nasional dan sub-nasional.

REDD+ memperlihatkan mekanisme tata kelola lingkungan kontemporer baru yang mencerminkan perubahan sifat dasar negara dan kemunculan aktor-aktor lain serta melibatkan sektor privat dan masyarakat. ${ }^{12}$ Proses tata kelola REDD+ mengikutsertakan banyak aktor, kepentingan dan aktivitas yang berbedabeda, melibatkan banyak sumber power dan otoritas formal maupun informalbadan-badan PBB, organisasi multilateral, pemerintah, perusahaan multinasional, komunitas lokal dan organisasi non-

\footnotetext{
${ }^{12}$ Bulkeley, Harriet and Peter Newell, 2010, Governing Climate Change, London: Routledge
}

pemerintah internasional dan lokal. $^{13}$ Kesemua aktor, kepentingan dan aktivitas saling mempengaruhi satu sama lain. REDD+ menunjukkan bagaimana kebijakan diimplementasikan melalui beberapa lapis pengambilan keputusan dan organisasi.

REDD+ kemudian banyak diadopsi oleh negara-negara berkembang. Indonesia adalah salah satunya dan merupakan negara yang paling aktif ikut serta di mana terdapat 30 pilot projects REDD+. Proyek Ulu Masen di Aceh termsauk salah satu proyek pertama dari pilot projects REDD+ di Indonesia. Hal ini disebabkan karena kondisi hutan di Aceh memerlukan perhatian di mana laju deforestasi semakin tidak terkendali pasca bencana tsunami 2004. Permintaan akan kayu bagi pembangunan kembali kota-kota yang hancur menjadi salah satu alasan deforestasi. Permintaan kayu meningkat empat kali lipat dari 33.249,25 m3 ke 120.209,50 m3. ${ }^{14} \quad$ Penyebab lain deforestasi di Aceh adalah pengalihan fungsi lahan, ekspansi infrastruktur dan kebakaran hutan. Dampaknya adalah banjr, polusi tanah dan air, masuknya hewan liar ke pemukiman dan perburuan hewan liar.

\footnotetext{
${ }^{13}$ Corbera, Esteve and Heike Schroeder, 2010, Governing and implementing REDD+, Environmental Science Policy, 14, 89-230, hlm 2 ${ }^{14}$ Husnan, et.al, 2008, Strategi dan Rencana Aksi Provinsi (SRAP) REDD+ Aceh
} 


\section{Implementasi REDD+ di Ulu Masen}

Sebelum REDD+ Ulu Masen berjalan di Aceh, Gubernur Irwandi Yusuf telah mencanangkan Aceh Green sebagai strategi pembangunan daerah Aceh. ${ }^{15}$ Hal ini tidak lepas dari kondisi pasca tsunami dan pasca konflik yang merusak hutan di Aceh. Di tahun 2006, Bank Dunia membiayai gerakan hijau di bawah pemerintahan Aceh melalui Aceh Forest and Environment Project (AFEP).

AFEP bertujuan untuk mengatasi deforestasi dan degradasi hutan yang disebabkan oleh kegiatan pembangunan pasca tsunami, terutama di ekosistem Leuser dan Ulu Masen. ${ }^{16}$ Selain itu, untuk mendukung terwujudnya Aceh Green Vision ini, pada tahun yang sama Gubernur Irwandi Yusuf mengeluarkan kebijakan moratorium logging yang melarang segala bentuk logging di Provinsi Aceh. REDD+ Ulu Masen merupakan strategi kelanjutan dari AFEP.

Selain itu, berdasarkan dokumen rancangan proyek Ulu Masen, inisiatif ini akan mampu meraup keuntungan dari hasil perdagangan karbon dengan lembaga pendanaan yang ditunjuk selama 30 tahun ke depan. Seluruh keuntungan akan disalurkan bagi kesejahteraan rakyat Aceh,

\footnotetext{
${ }^{15}$ Dunlop, Jane, 2009, REDD, Tenure And Local Communities: A Study From Aceh, Indonesia, International Development Law Organization

${ }^{16}$ Kasia, Rahmad, et.al, 2011, Penanganan Masalah Pembalakan Liar di Kawasan Ulu Masen Aceh, FFI Aceh Programme, November 2011
}

dimana $50 \%$ dari total keuntungan akan digunakan untuk ganti rugi lahan yang tumpang tindih dengan lahan proyek. ${ }^{17}$

Tujuan lainnya adalah melindungi kawasan hutan seluas 750.000 hektare yang mencakup 6 (enam) kabupaten yaitu Aceh Barat, Aceh Jaya, Aceh Besar, Pidie, Pidie Jaya dan Bireuen. Wilayah ekosistem enam kabupaten inilah yang disebut ekosistem Ulu Masen. Perlindungan hutan di ekosistem Ulu Masen dianggap penting karena akan memberikan layanan sosial sekaligus kontribusi ekonomi yang cukup besar dengan sekitar 300.000 orang yang tinggal di dalam kawasan ataupun berbatasan langsung dengan kawasan proyek tersebut.

Untuk menunjang komitmen tersebut, Gubernur Aceh Irwandi Yusuf mengeluarkan kebijakan moratorium perlindungan hutan dari pembalakan liar dan ancaman alih fungsi lahan. Adapun pelaksanaan proyek di lapangan dilakukan melalui kerjasama multipihak (lintas sektor): pemerintah provinsi Aceh, Fauna \& Flora Internasional $(\mathrm{FFI})^{18}$ Carbon

\footnotetext{
${ }^{17}$ Forest People Programme, 2011, Aceh: Proyek Uji Coba REDD+ Ulu Masen. Seri Briefing Hakhak, Hutan dan Iklim, May 24, 2015, hlm 1

${ }^{18}$ Fauna\&Flora International merupakan Nongovernmental Organization global yang bekerja di lebih dari 40 negara dengan 140 proyek. FFI berfokus pada masalah biodiversitas alam dan bertujuan menunjukkan kepada dunia pentingnya masalah biodiversitas. FFI terbentuk sejak lebih dari 100 tahun dan merupakan organisasi konservasi pertama di dunia. Gerakan awal organisasi FFI di Afrika telah berhasil menciptakan
} 
Conservation (CC). ${ }^{19}$ Masyarakat adat yang tersebar dalam mukim juga dilibatkan. ${ }^{20}$ Masyarakat adat di sekitar Ulu Masen berada dalam 61 wilayah kemukiman dengan 200 gampong, di mana masing-masing memiliki Kepala Mukim masing-masing. Masing-masing gampong ini dipimpin lagi oleh seorang geuchik atau kepala desa.

Pada awal persiapan rancangan proyek REDD+ Ulu Masen, Pemerintah Daerah Aceh menerbitkan kebijakan dan jaminan hukum yang kredibel bagi keberlangsungan proyek. Pemda mendirikan dan menunjuk Badan Pengelola Kawasan Ekosistem Leuser (BPKEL), menerbitkan moratorium logging 2007 serta Keputusan Gubernur N0.522.21/284/2008 untuk pemberantasan pembalakan liar dan masih banyak lagi.

FFI merupakan mitra Pemerintah Daerah Aceh yang bertanggungjawab terkait dengan penguatan hak-hak

beberapa lahan yang harus diproteksi, seperti Taman Nasional Kruger dan Serengeti.

Informasi lebih lanjut dapat diakses melalui http://www.fauna-flora.org/about/our-history/

${ }^{19}$ Carbon Conservation adalah perusahaan jual-beli karbon asal Australiayang dimiliki oleh pengusaha sekaligus aktivis LGBT Dorjee Sun. Perusahaan ini terkenal akibat film documenter the Burning Season pada tahun 2008 serta aktivitasnya sebagai perusahaan hijau. Dorjee Sun sebagai pemilik CC dianugerahi penghargaan Heroes of the Environment (2009), penghargaan Carbon Finance Deal of the Year (2008) dan diberi penghargaan oleh African Rainforest Conservancy atas kerja kerasnya menangani deforestasi.

Informasi lebih lanjut diakses melalui http://www.carbonconservation.com/

${ }^{20}$ Kasia, et.al., 2011, Op.Cit., hlm 2 masyarakat adat terhadap kepemilikan lahan hutan, pembuatan peta wilayah kepemilikan adat, memfasilitasi partisipasi masyarakat adat dalam perencanaan tata ruang di level kabupaten dan provinsi. Berkaitan dengan proyek REDD+ Ulu Masen, FFI terlibat dalam memberikan capacity building, bantuan teknis dan saran kebijakan kepada pemerintah Aceh. Free, Prior, and Informed Consent (FPIC) mulai dijalankan pada tahun $2010 .^{21}$

$\mathrm{CC}$ merupakan perusahaan pialang karbon asal Australia yang terkenal sebagai perusahaan hijau. Dalam proyek ini, CC membantu pembuatan desain proyek, perhitungan estimasi cadangan karbon, pendanaan dan penjualan, bantuan struktur legal dan hubungan dengan mitra serta keterlibatan sektor swasta. CC juga berhasil mengajukan dana investasi dari Merrill Lynch untuk membiayai lahan sebesar 750.000 ha. Nilai investasi yang disepakati mencapai US\$ 9 juta, berjangka waktu 4 (empat) tahun. Dalam perjanjian pra-pembelian antara Pemda Aceh dan Merrill Lynch disebutkan bahwa Merrill

21 Istilah FPIC ini sebenarnya merupakan mekanisme REDD+ yang dicetuskan oleh UNREDD sebagai badan yang turut membantu tahap kesiapan implementasi REDD+. FPIC ini dimaksudkan agar dalam implementasi REDD+, negara-negara tetap memperhatikan dampak sosial yang muncul terhadap masyarakat adat. Oleh karenanya, perlu ada sosialisasi dan pernyataan kesediaan dari masyarakat adat di sekitar proyek terhadap program REDD+ yang akan diadakan. 
Lynch akan membeli emisi bersertifikat dengan harga US\$ 4 per ton.

Secara teknis, para pihak yang terlibat telah berhasil menyusun dokumen perencanaan proyek yang memasukkan dan memperhatikan permasalahan mengenai insentif REDD+ serta pelaksanaannya di Ulu Masen. Rancangan royek ini juga adalah proyek REDD+ paling pertama di dunia yang berhasil memenuhi standar the Climate, Community and Biodiversity Alliance $(\mathrm{CCBA}){ }^{22}$ Audit terhadap program perencanaan proyek menyatakan proyek memuaskan dan diberikan penghargaan perak. Standar ini merupakan salah satu prasyarat penjualan karbon dan digunakan oleh banyak proyek REDD+ untuk menyakinkan investor dan pembeli karbon mengenai kualitas proyek. Proyek Ulu Masen hanya memerlukan satu langkah lagi yaitu sertifikasi standar Voluntary Carbon Standard (VCS).

Proyek Ulu Masen berjangka waktu 30 tahun dan dibagi dalam dua tingkatan yang berkesinambungan dimana tidak bisa berjalan tanpa kesuksesan di tahap sebelumnya. Tahap pertama adalah preREDD Credit Stage dengan rentang waktu 2008-2012 yang terdiri dari empat proses. Tahap pertama ini disebut juga sebagai Demonstration Activities dan menghendaki adanya target pencapaian insentif dari penjualan verified emission reductions (VERs) atau early-action credits sebesar 3.3 juta kredit karbon pertahun serta memonitor pembalakan liar. Proyek ini juga direncanakan akan di integrasikan secara nasional (pasca 2012). Dengan kata lain, kredit karbon yang dihasilkan akan dimasukkan ke dalam skenario "baseline" referensi emisi nasional sehingga karbon bisa diperdagangkan dalam skema UNFCCC.

Terlepas dari aktor-aktor yang terlibat secara langsung dalam proyek, terdapat pula aktor-aktor lain yang terlibat secara tidak langsung di berbagai level tata kelola. Hal ini tidak terlepas dari karakter dasar REDD+, dimana proses kebijakan dan rezim terjadi pada lintas skala serta lintas partisipan oleh berbagai aktor publik dan privat. Aktor-aktor ini memiliki peranan yang penting dalam koordinasi serta implementasi kebijakan dan kepentingan masing-masing pada proyek REDD+ Ulu Masen. Tabel berikut memuat aktor-aktor yang terlibat dari berbagai level:

\footnotetext{
${ }^{22}$ Rainforest Alliance, 2008.
} 


\begin{tabular}{|c|c|c|}
\hline LEVEL & AKTOR & PERAN \\
\hline \multirow{4}{*}{ Internasional } & $\begin{array}{l}\text { UNFCCC/COP*: negara } \\
\text { maju atau ANNEX I dan } \\
\text { negara berkembang. }\end{array}$ & $\begin{array}{l}\text { Pembentukan aturan pada level } \\
\text { global dan menjadi wadah } \\
\text { perundingan negara-negara. }\end{array}$ \\
\hline & $\mathrm{CCBA}^{*}$ & $\begin{array}{l}\text { Melakukan audit yang akan } \\
\text { menentukan apakah sebuah proyek } \\
\text { REDD+ layak dijalankan atau tidak. }\end{array}$ \\
\hline & Norwegia & $\begin{array}{l}\text { Penyandang dana melalui proyek } \\
\text { pemerintah, yaitu insentif bagi } \\
\text { kehutanan. }\end{array}$ \\
\hline & UN-REDD & $\begin{array}{l}\text { Lembaga kerjasama antara UNDP, } \\
\text { FAO dan UNEP untuk memberikan } \\
\text { bantuan teknikal. }\end{array}$ \\
\hline \multirow{7}{*}{ Nasional } & Kementerian Kehutanan* & $\begin{array}{l}\text { Pemilik proyek REDD+ di seluruh } \\
\text { Indonesia, merujuk pada hukum dan } \\
\text { UU. }\end{array}$ \\
\hline & Satgas REDD+* & $\begin{array}{l}\text { Membentuk lembaga dan skema } \\
\text { REDD+ nasional. }\end{array}$ \\
\hline & BP-REDD+** & $\begin{array}{l}\text { Badan yang membawahi seluruh } \\
\text { proyek REDD+ nasional. }\end{array}$ \\
\hline & Bappenas & $\begin{array}{l}\text { Memasukkan program REDD+ ke } \\
\text { dalam perencanaan nasional. }\end{array}$ \\
\hline & CIFOR $*$ & $\begin{array}{l}\text { CSO yang membantu mengkaji } \\
\text { REDD+ dari sisi keilmuan. }\end{array}$ \\
\hline & WALHI & $\begin{array}{l}\text { CSO yang vokal dan kontra } \\
\text { terhadap keberadaan REDD+ di } \\
\text { Indonesia. }\end{array}$ \\
\hline & AMAN & $\begin{array}{l}\text { CSO yang vokal dan pro terhadap } \\
\text { keberadaan REDD+ karena } \\
\text { dianggap membantu masyarakat }\end{array}$ \\
\hline
\end{tabular}




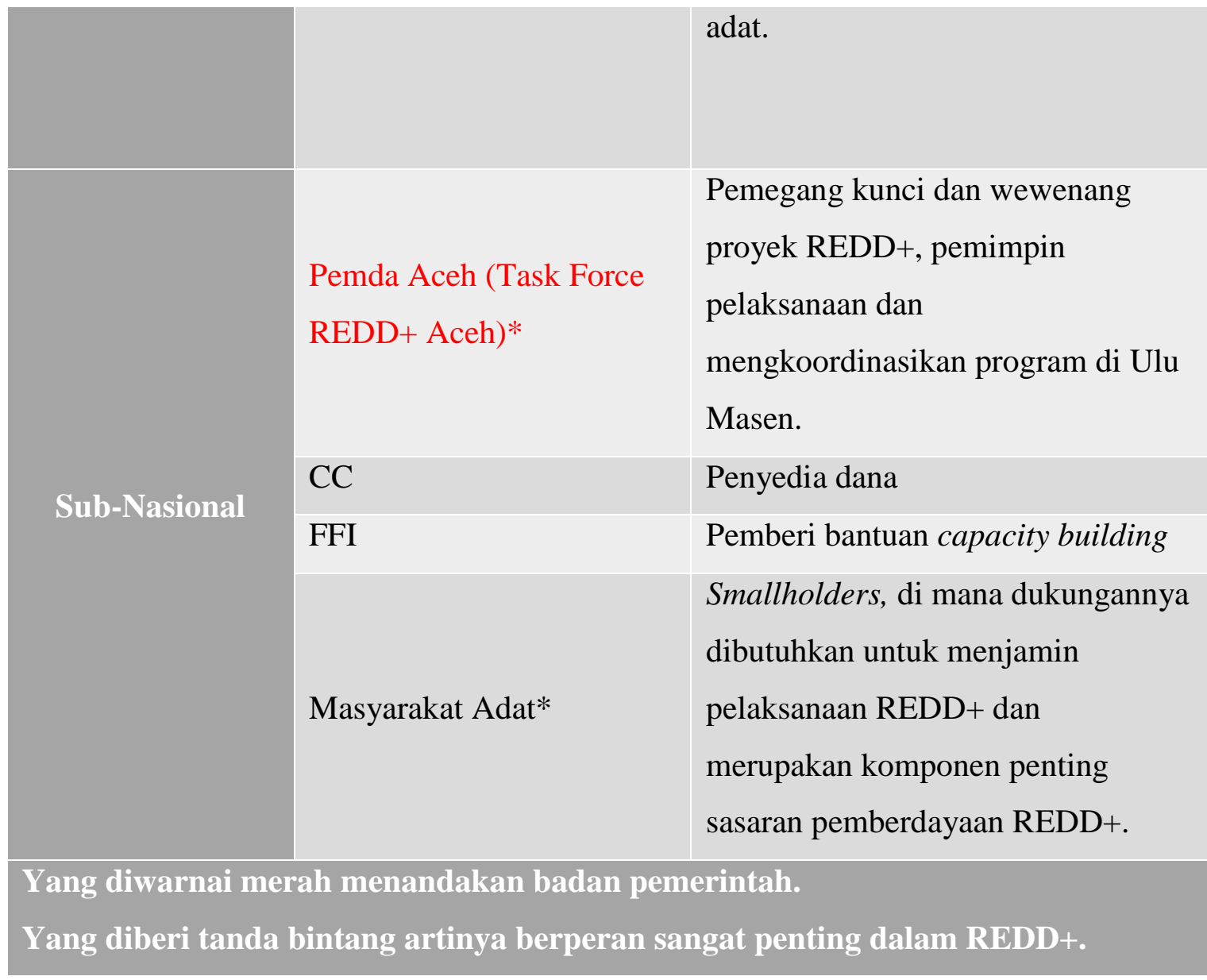

\section{Sumber: Olahan Penulis}

Namun dalam proses pelaksanaan, berbagai target pada tahapan pertama tidak terealisasi. Dengan demikian, tahap kedua tidak dapat dilaksanakan karena gagalnya pencapaian target tahap sebelumnya yang penting bagi keberlanjutan proyek. Hal ini diperkuat oleh penemuan Chris Lang dari REDD Monitor ${ }^{23}$ pada tahun 2012 yang

\footnotetext{
${ }^{23}$ REDD Monitor adalah sebuah organisasi nirlaba yang berfokus pada masalah kehutanan dan REDD+. Organisasi ini dijalankan sejak Oktober 2008 secara independen oleh Chris Lang, seorang master Kehutanan dan Penggunaan Tanah dari Insitut Kehutanan Oxford. Ia banyak terlibat dalam berbagai gerakan perlindungan kehutanan, misalnya dibawah organisasi TERRA

(http://terraper.org/mainpage/index_en.php?langs=e n). Selanjutnya ia aktif dalam gerakan World Rainforest Movement (http://www.wrm.org.uy)
}

menyatakan bahwa proyek ini berhenti tanpa adanya pemberitahuan yang jelas dari para pengelola proyek.

Pada akhir tahun 2012, tidak ada satu ton pun karbon kredit karbon yang dihasilkan oleh proyek REDD+ Ulu

yang berfokus pada tree plantation dan industri pulp dan kertas. Pendanaan REDD Monitor diperoleh dari berbagai organisasi sosial dan lingkungan seperti FERN, Rainforest Foundation Norway, Rainforest Foundation UK, Global Witness, Corner House, Arbeitsgemeinschaft Regenwald und Artenschutz. Selain itu, REDD Monitor juga didanai secara tidak langsung oleh Komisi Eropa. REDD Monitor aktif memonitor proyek REDD di negara-negara yang mengaplikasikan mekanisme ini. Pada kasus Indonesia, REDD Monitor aktif meneliti proyek Ulu Masen Aceh pada tahun 2012 didanai oleh Samdhana Institute dan World Rainforest Movement.

Lihat di http://www.redd-monitor.org/about/ dan Wawancara dengan Chris Lang, 10 April 2015. 
Masen. Di pihak lain, pembalakan liar semakin meningkat dengan adanya proyek REDD+ Ulu Masen terutama dilakukan oleh masyarakat adat. ${ }^{24}$ Proyek pengurangan emisi di ekosistem Ulu Masen juga semakin meningkatkan emisi karbon yang dihasilkan oleh Provinsi Aceh akibat peningkatan kegiatan deforestasi dan degradasi hutan di luar wilayah luar cakupan program. Dengan demikian sulit memverifikasi kredit karbon yang dihasilkan karena tidak memiliki nilai kompensasi akibat kebocoran.

\section{Analisis Penyebab Kegagalan REDD+}

\section{Ulu Masen}

Pada dasarnya, REDD+ merupakan proses desain politik pada level global, nasional dan sub-nasional. ${ }^{25}$ REDD+ menjadi sebuah terobosan kontroversial dalam mitigasi perubahan iklim yang mengikutsertakan berbagai aktor di berbagai level dengan kepentingan dan agenda masing-masing. Acuan dasarnya adalah dengan adanya beragam aktor dengan beragam sasaran dan kepentingan, akan terjadi sebuah multiple linkages

\footnotetext{
${ }^{24}$ Soriano, Eleonor Baldo, et.al, 2010, Apa Itu REDD? Sebuah Panduan Untuk Masyarakat Adat, Tebtebba: AIPP, FPP, IWGIA, hlm 44-45

${ }^{25}$ Angelsen, Arild and Sheila Wertz-Kanounnikoff, 2009, Global And National REDD+ Architecture:

Linking Institutions And Actions, dalam Arild Angelsen, M. Brockhaus, M. Kanninen, E. Sills, W. D. Sunderlin and S. Wertz-Kanounnikoff (eds), 2009, Realising REDD+: National Strategy and Policy Options, Bogor, Indonesia: Center for International Forestry Research, hlm xiv
}

(keterkaitan beberapa sektor atau elemen dan anggota) yang disebut dengan kemitraan lintas sektor. Keadaan ini akan memaksimalisasi hasil akhir sebuah proyek REDD+ karena terdapat tujuan kolektif di antara mereka, yakni menyukseskan terlaksananya REDD+ di negara-negara berkembang.

Terdapat interdependensi antara sasaran para pelaku, aturan hingga kepentingan pada masing-masing level. Yang terjadi pada level global akan mempengaruhi desain dan implementasi di semua level. Demikian pula sebaliknya, yang terjadi pada level sub-nasional dan nasional akan menyebabkan apa yang telah diputuskan pada level sebelumnya tidak terlaksana dan menghambat proses penerapan REDD+.

Dengan demikian, jika kemitraan ini dilaksanakan dengan baik maka diyakini bahwa pelaksanaan penerapan REDD+ akan berhasil. Sedangkan dalam kasus implementasi REDD+ di Ulu Masen ditemukan beberapa faktor penyebab kegagalan kemitraan lintas sektor yang tersebut akibat ketiadaan sinergi serta koordinasi pada masing-masing level.

\section{Level Internasional}

Pada level internasional, United Nations Framework Convention on Climate Change (UNFCCC) merupakan badan yang membawahkan mekanisme 
REDD+ dimana di dalamnya terdapat berbagai aktor yang terlibat yakni negara maju (ANNEX I dan donor), negara berkembang, NGOs, perusahaan hingga individual. Selain itu, ada pula badan independen the Climate, Community and Biodiversity Alliance (CCBA) yang terlibat dalam proses audit kelayakan proyek REDD+.

Pada level internasional, sasaran yang dimiliki aktor adalah untuk memaksimalisasi interest dalam perundingan guna mencapai aturan rezim yang dianggap dapat mengakomodasi semua pihak di dalamnya. Tujuan kolektif yang hendak dicapai adalah terciptanya aturan rezim, terlaksananya aturan dan berlangsungnya REDD+ di negara berkembang.

Akan tetapi tetapi sasaran dan tujuan kolektif tidak tercapai akibat ketidakjelasan Konsep REDD+ di Level Internasional yang meliputi:

\section{a. Perubahan Substansi dan Perdebatan}

\section{Aturan di Level Internasional}

Setiap tahunnya, COP dalam ranah UNFCCC terus dilakukan dan konsep serta skema REDD+ direvisi atau diubah. Hingga saat ini, pada level internasional, terdapat beberapa aspek-aspek kunci yang masih diperdebatkan serta belum jelas dan final. Padahal, hal-hal tersebut diperlukan dalam mengembangkan skema REDD+ agar dapat diaplikasikan secara universal. ${ }^{26}$ Aspek-aspek tersebut adalah mengenai jangkauan, mekanisme pendanaan, skala, level referensi dan langkah-langkah safeguard bagi komunitas lokal atau masyarakat adat.

\section{b. Ketiadaan Aturan Tenurial pada} Skema REDD+ Global Memicu Konflik REDD+ ternyata memunculkan konflik baru dan memperuncing konflik lama. ${ }^{27}$ Efek terbesar adalah mengancam populasi yang selama ini tinggal dan bergantung pada hutan terutama ketika hak, masalah tenurial dan partisipasi mereka tidak terjamin. ${ }^{28}$ Keberadaan REDD+ justru menimbulkan pertanyaan: siapa yang memiliki hak atas pohon, karbon hingga pengambilan keputusan serta hak atas benefit sharing yang dijanjikan. ${ }^{29}$ Padahal, hak tenurial yang jelas dan pasti diidentifikasi sebagai salah satu elemen kunci bagi keberhasilan skema konservasi hutan, termasuk di dalamnya adalah skema REDD+. ${ }^{30}$

\footnotetext{
${ }^{26}$ Ibid., hlm 27

${ }^{27}$ Knox, A, et.al, 2011, Land Tenure And Payment For Environmental Services: Challenges And Opportunities For Redd+, Land Tenure Journal, 2, 7-55, hlm 17-55

${ }^{28}$ Peskett, K, et.al., 2008, Making REDD Work For The Poor, London, UK: Overseas Development Institute and IUCN

${ }^{29}$ Yasmi, Y., L. Kelley, D. Murdiyarso, and T. Patel, 2012, The Struggle Over Asia's Forests: An Overview Of Forest Conflict And Potential Implications For REDD+, International Forestry Review, 14(1), 99-109, hlm 107

${ }^{30}$ Larson, Anne M., et.al, 2013, Land Tenure And REDD+: The Good, The Bad And The Ugly, Global Environmental Change, 23, 678-689.
} 
REDD+ dirancang untuk diimplementasikan di negara berkembang, di mana hutan dan degradasi hutan menjadi penyumbang terbesar GRK. Di negara berkembang, terutama di Asia, konflik tenurial serta perebutan sumber daya alam justru adalah masalah terbesar yang belum dapat teratasi hingga kini. Nyaris $75 \%$ hutan di Asia merupakan area perebutan dan konflik berdarah dalam 20 tahun terakhir. $^{31}$

Skema REDD+ yang dibuat dalam ranah internasional hanya secara implisit menyebutkan masalah manajemen hutan atau konflik tenurial tersebut. Skema menyarankan adanya 3 (tiga) tahapan (misalnya, tahap transisi dan implementasi secara penuh) yang bertujuan agar safeguards bagi dampak sosial berhasil dijalankan dalam setiap tahapan. Hanya saja, belum ada keputusan dalam forum REDD+ global (UNFCCC) yang secara eksplisit mengatur hal ini. Segala bentuk masalah tenurial diserahkan kepada hukum nasional negara masing-masing.

c. Aturan REDD+ Tidak

\section{Mengakomodasi Masyarakat Adat}

Upaya REDD+ dalam menghadapi perubahan iklim dan memberikan solusi terhadap masalah deforestasi di negara berkembang ternyata tidak "ramah" terhadap masyarakat adat. Berbagai aturan

${ }^{31}$ Ibid
REDD+ justru mengisolasi masyarakat adat dari proses pengambilan keputusan dan mengabaikan hak-hak komunitas adat yang bergantung pada hutan.

Aturan-aturan yang berkaitan dengan safeguards bagi masyarakat adat tidak ditentukan dengan jelas. Dalam prakteknya, semua diserahkan kepada negara atau pengelola proyek, yang diharapkan akan mematuhi aturan yang telah disepakati dalam COP. Hal ini menyebabkan munculnya dampak negatif aturan REDD+ terhadap masyarakat adat. Berdasarkan penelitian Asia Indigenous Peoples Pacts (AIPP) dan Forest People Programme (FPP) aturan REDD+ menyebabkan: ${ }^{32}$

- Relokasi dan perampasan lahan. Pengelolaan hutan berbasis masyarakat akan diubah dengan pendekatan "pagar dan denda". Di bawah pendekatan tersebut, akan terjadi peningkatan pengkotakkan wilayah (zoning) yang tidak memperbolehkan masyarakat adat untuk memasuki atau memanfaatkan daerah hutan yang diakui secara formal atau legal sebagai kawasan lindung karbon.

- Meningkatnya ketidaksetaraan dan konflik sosial. Peningkatan nilai hutan secara ekonomi dan manfaat

\footnotetext{
${ }^{32}$ Soriano, Eleanor Baldo, et.al., 2010, Ibid., hlm 44-45
} 
yang diperkirakan dari program REDD+ menimbulkan lebih banyak konflik tapal batas. Pemilik hutan (landlord) dapat mengakuisisi lahan-lahan besar dan mendapatkan manfaat pendanaan REDD+, sedangkan masyarakat adat tidak menerima apapun.

- Larangan terhadap praktek pemanfaatan hutan berdasarkan cara-cara adat. Tidak hanya peladangan gilir balik, namun bentuk pemanfaat hutan dengan cara adat lainnya seperti pembakaran hutan terkontrol untuk menciptakan keragaman habitat bagi hewan buruan dan hewan ternak, pengumpulan kayu bakar, penebangan pohon bagi bahan bangunan, bahkan mengumpulkan hasil hutan lainnya kini dianggap salah satu bentuk degradasi hutan menurut program-program REDD+. Dengan demikian, program REDD+ mengancam keamanan sumber penghidupan masyarakat adat.

\section{d. Irelevansi Mekanisme REDD+}

Irelevansi mekanisme REDD+ merujuk pada kenyataan bahwa mekanisme REDD+ terlalu sulit untuk dijalankan. Jangkauan-jangkauan yang disepakati memiliki kesulitan implementasi yang terlalu tinggi. ${ }^{33}$ Sebagai mekanisme yang berupaya memberikan manfaat kepada masyarakat adat sekaligus melindungi hutan, REDD+ justru menciptakan mekanisme kompleks.

Mekanisme kompleks ini membutuhkan banyak konsultan berbiaya mahal serta ahli untuk menghitung cadangan karbon hutan dan mensertifikasi bahwa reduksi emisi telah tercapai. Yang menjadi masalah, harga karbon juga sangat rendah yang berarti hanya persentase kecil dari pembayaran karbon yang juga sedikit itu akan mencapai komunitas.

\section{e. Inkonsistensi dan Lemahnya Audit} CCBA

$$
\text { Standar penilaian }
$$

CCBA menentukan apakah sebuah proyek layak dijalankan. Klaim dari standar CCBA adalah "best practices to generate significant benefits". Namun, hasil penelitian yang dilakukan oleh Goran Eklof (2013) menyebutkan bahwa sertifikasi CCBA tidak serta merta menjamin akan adanya perlindungan serta manfaat bagi komunitas lokal maupun biodiversitas. ${ }^{34}$

\section{Permasalahan yang ditemukan di} berbagai proyek nyaris sama, yakni

\footnotetext{
${ }^{33}$ Wiersema, Annecoos, 2014, Climate Change, Forests and International Law: REDD's Descent into Irrelevance, Vanderbilt Journal of International Law, 47(1)., hlm 4-5

${ }^{34}$ Eklof, Goran, 2013, REDD plus or REDD

"Light"? - Biodiversities, Communities And Forest, Carbon Conservation, Swedish Society for Nature Conservation
} 
masalah tenurial, FPIC, benefit sharing, perdagangan karbon dan biodiversitas. Hal ini menunjukkan bahwa dengan tersertifikasinya sebuah proyek REDD+ melalui CCBA tidak serta merta menjadikan proyek tersebut kredibel. Dengan demikian, sertifikasi CCBA tidak bisa dijadikan sebuah pegangan bahwa komunitas akan diuntungkan ataupun proyek akan berjalan.

Sekalipun dalam sertifikasi CCBA mewajibkan adanya FPIC, CCBA tidak menuliskan secara jelas proses FPIC seperti apa yang pantas disebut berjalan atau tidak berjalan. Selain itu, dalam mekanisme pembagian manfaat dari penjualan kredit karbon, meskipun negosiasi masih berjalan dan belum mendapatkan kesepakatan, maka sertifikasi tetap diterbitkan.

\section{Level Nasional}

Pada level nasional di Indonesia, mekanisme REDD+ secara otomatis berada di bawah Kementerian Kehutanan sesuai dengan amanat UU yang berlaku. Namun, ternyata implementasi REDD+ di Indonesia melibatkan berbagai lembaga negara baik yang langsung maupun tidak langsung terlibat dalam implementasi REDD+

Lembaga-lembaga di tingkat nasional yang juga akhirnya terlibat secara langsung adalah Satuan Tugas REDD+
Nasional, Badan Pengelola REDD+ Nasional (BP REDD+). Selain itu, Bappenas juga turut serta dikarenakan REDD+ jmasuk dalam ranah pembangunan, yakni pembangunan bidang kehutanan. Masalah hutan juga berkaitan dengan penetapan tanah yang dijadikan area proyek sehingga melibatkan Badan Pertanahan Nasional (BPN). Bahkan untuk masuknya proyek beserta kerangka finansialnya juga melibatkan Kementerian Luar Negeri dan Kementerian Keuangan.

Sasaran pelaku yang terlibat langsung di level nasional adalah masalah perebutan pengaruh masing-masing lembaga dalam menjalankan proyek REDD+, dalam hal ini terutama antara Kementerian Kehutanan dan Satgas REDD+ serta BP REDD+ Nasional. Sasaran Kemenhut lainnya dalah terkait penetapan lahan yang ditetapkan sebagai hutan proyek dan bukan berada di bawah wewenangnya karena $70 \%$ lahan hutan berada di bawah koordinasi langsung Kemenhut.

Adapun tujuan kolektif yang ingin dicapai secara nasional dari para pelaku di level ini adalah terintegrasinya berbagai proyek percontohan REDD+ di berbagai daerah dalam satu payung nasional. Dengan terintegrasinya seluruh proyek akan membantu mencapai target pengurangan emisi nasional sebesar $26 \%$ per tahun 2020 (BP REDD+ Nasional 
Indonesia, n.d). Oleh karenanya, berbagai proyek percontohan di berbagai daerah sebenarnya sangat penting untuk didukung oleh pemerintah nasional karena pada akhirnya akan berada di bawah payung nasional.

Dalam perjalanannya, ketika berupaya mencapai kepentingan tersebut terjadi banyak benturan. Benturan tersebut terjadi bukan hanya di antara para aktor tetapi juga benturan-benturan yang disebabkan oleh kondisi ekonomi politik Indonesia yang belum menunjang bagi pelaksanaan REDD+ yang berupaya mengurangi deforestasi serta banyaknya benturan aturan serta UU. Selain itu, terdapat pula masalah tenurial yang belum terselesaikan baik.

Permasalahan di level nasional juga pelik karena kemudian terkait langsung dengan daerah Aceh, terkait UU hingga pengaturan lahan hutan yang dijadikan proyek. Pemerintah pusat mengklaim bahwa segala sesuatu yang berkaitan dengan proyek REDD+ harus melalui Kementerian Kehutanan dan Pemda Aceh tidak memiliki hak pelaksanaan proyek secara mandiri. Padahal berdasarkan mekanisme MLG dalam REDD+, aktor internasional dapat berkomunikasi langsung dengan aktor manapun yang menjadi sasaran pelaksanaan proyek REDD+ tersebut.

\section{a. Kebijakan-Kebijakan Pro-Deforestasi}

Untuk memperoleh gambaran tentang faktor-faktor yang mempengaruhi permasalahan nasional, perlu dilihat mengenai konteks ekonomi politik Indonesia. Hal ini disebabkan masalah ekonomi politik merupakan sebuah prasyarat untuk memahami kesulitan melaksanakan program REDD+ di wilayah Indonesia. Salah satu permasalahan nasional utama yang sangat berpengaruh pada penyelenggaraan proyek sub-nasional REDD+ di Indonesia merupakan masalah ekonomi.

Sunderlin dan Roesosudarmo dalam Widiaryanto, menyatakan bahwa di Indonesia, dalam level lokal maupun regional, kebijakan pemerintah bertujuan untuk meningkatkan kualitas kehidupan masyarakat melalui peningkatan pendapatan perkapita. $^{35}$ Oleh karena itu, berlanjutnya keberlangsungan deforestasi dan degradasi hutan selama ini sebenarnya disebabkan oleh kebijakan pemerintah yang mementingkan pembangunan serba cepat. Pemerintah terus mengandalkan sumber daya alam dari hutan untuk membiayai pembangunan. Sektor kehutanan merupakan sektor dengan sumbangan devisa, output hingga sumber

\footnotetext{
${ }^{35}$ Widiaryanto, Pungky, 2012, Does the Pressure of Population and Poverty Cause Deforestation?, Yogyakarta, Indonesia: JSP, hlm 85
} 
tenaga kerja terbesar dibandingkan sektor perekonomian lainnya. ${ }^{36}$

Kebijakan pemerintah yang mengandalkan sumber daya alam dapat dilihat dari data keuangan APBN 2010. ${ }^{37}$ Data APBN menunjukkan bahwa sektor ini berkontribusi sebesar 73,9\% untuk bagian pendapatan negara bukan pajak (PNPB). SDA juga berkontribusi sekitar $30 \%$ dari keseluruhan hasil produk domestik bruto (PDB) dan sektor kehutanan khususnya menyumbang $2,4 \%$.

Pendapatan dari sektor yang mengeksploitasi SDA terus meningkat karena adanya kebijakan-kebijakan yang mendorong investasi dan terciptanya iklim investasi SDA yang aman. Menurut Cecilia Luttrell (CIFOR), kebijakan yang terus mendorong eksploitasi hutan, antara lain $(2011):^{38}$

a. keringanan pajak (PP No. 1/2007 Pasal 2 mengenai potongan pajak $30 \%$ pada laba bersih dari nilai investasi selama enam tahun atau $5 \%$ setiap tahunnya)

b. izin pertambangan kawasan hutan lindung (PP No. 2/2008)

\footnotetext{
${ }^{36}$ Ridho, Dodhik and M. Fadhil Hasan, 2012, Ekonomi Politik Kehutanan: Mengurai Mitos Dan Fakta Pengelolaan Hutan, 2nd ed, Jakarta, Indonesia: INDEF, hlm xviii

${ }^{37}$ Indrarto, Giorgio Budi, et,al, 2010, The Context of REDD+ in Indonesia, Bogor, Indonesia: CIFOR, hlm 40

${ }^{38}$ Luttrell, Cecilia, 2011, Lessons For REDD+ From Measures To Control Illegal Logging In Indonesia, CIFOR Working Paper 74
}

c. pengembangan lahan pangan dan lahan energi (PP No. 18/2010)

d. pengembangan biofuel (Instruksi Presiden No. 1/2006) tentang penyediaan dan pemanfaatan bahan bakar nabati sebagai bahan bakar alternatif atau bahan bakar hijau)

e. pembukaan lahan bagi perkebunan kelapa sawit (Peraturan Menteri Pertanian No. 26/Permentan/OT.140/2/2007 yang mengizinkan 100.000 hektar lahan untuk perkebunan sawit di Papua, Peraturan Menteri Kehutanan No. P22/Menhut-II/2009 yang memberikan dasar hukum bagi perusahaan kelapa sawit memiliki lahan 100.000-200.000 hektar di Papua)

\section{b. Permasalahan Tenurial}

Pemerintah Indonesia tidak memiliki kapasitas untuk mendefinisikan secara jelas hak properti dan hak tenurial atau kepemilikan tanah di sektor kehutanan. Penegakan hukum berkaitan dengan hak properti dan tenurial juga lemah sehingga merugikan masyarakat adat dan seringkali tenurial hutan justru diberikan sebagai konsesi kepada perusahaan besar atau diberikan kepada tuan tanah yang menyewakan kembali 
kepada petani atau masyarakat di sekitar hutan. $^{39}$

Selain itu, UU Pertanahan di Indonesia mengakui hak tanah adat tetapi UU Kehutanan mementahkan aturan tersebut. Klaim dari Kementerian Kehutanan menyebutkan bahwa 70\% lahan di Indonesia dikuasai oleh lembaganya. ${ }^{40}$ Akibatnya, tumpang tindih klaim atas tenurial di Indonesia berlapis dan menghambat bahkan menyebabkan implementasi REDD+ terhenti.

\section{c. Kontestasi Antar Lembaga}

\section{Pemerintah Pusat}

Meskipun Indonesia merupakan negara pertama yang menerapkan dan mengadopsi regulasi REDD+ serta memperkenalkan kerangka hukum REDD+ nasional, pemerintah belum mampu menunjukkan langkah koheren dalam pengaturan dan pengelolaan REDD+ secara nasional. ${ }^{41}$ Terjadinya tumpang tindih undang-undang pengaturan REDD+ menyulitkan proyek ketika dimulai. Misalnya, dalam UU No. 41/1999 pasal 5 ayat 3 dinyatakan bahwa penetapan status hutan dilakukan pemerintah pusat.

\footnotetext{
${ }^{39}$ Ridho, Dodhik and M. Fadhil Hasan, 2012, Op.Cit.,

${ }^{40}$ Larson, et.al., 2013, Op.Cit, hlm 683

${ }^{41}$ Huber, Suzy, 2013, Indonesia Kerangka Hukum REDD+, April 4, 2015,

http://theREDDdesk.org/sites/default/files/resources /pdf/2013/REDD_indonesia_bahasa_20_may.pdf, hlm 3
}

Oleh karenanya, jika merujuk pada UU tersebut maka pemerintah pusat berperan penting dan dominan dalam mengontrol, mengatur dan menetapkan status hutan. UU ini menyebabkan pemerintah pusat berkuasa untuk mengontrol hubungan antara hutan dan manusia, dimana pemerintah dapat mengizinkan maupun menolak aktivitas masyarakat adat/lokal di hutan. ${ }^{42}$

Namun, Peraturan Pemerintah No. 44 Tahun 2004 tentang Perencanaan Kehutanan pasal 15 menyatakan bahwa pengukuhan kawasan hutan ditetapkan oleh Kementerian Kehutanan, dalam hal ini adalah Menteri Kehutanan. Dengan demikian, penetapan mana kawasan hutan dan bukan hanya ada di tangan Kementerian Kehutanan.

Di samping tumpang tindih UU, terjadi pula tumpang tindih pembagian tugas dan tanggungjawab antara badanbadan pemerintah nasional. Permenhut No.36/Menhut-II/2009 yang dikeluarkan oleh Kementerian Kehutanan mengatur skema pendanaan REDD+ yang justru kemudian ditentang oleh Kementerian Keuangan yang menyatakan Kementerian Kehutanan tidak berwenang mengatur isuisu finansial. Kementerian Keuangan

\footnotetext{
${ }^{42}$ Arnold, Luke Lazarus, 2008, Deforestation in decentralised Indonesia: what's law got to do with it?. Law, Environment and Development Journal, 4(2), 77-100, hlm 86
} 
menilai bahwa isu finansial masuk dalam ranah Kementerian Keuangan. ${ }^{43}$

Selain itu, adanya dualisme kebijakan pertanahan di Indonesia. Dalam kawasan hutan, legalitas pemanfaatan tanah adalah melalui izin dari Kementerian Kehutanan. Sedangkan, di luar kawasan hutan atau yang disebut dengan Area Peruntukan Lain (APL), administrasi dan penguasaan tanah terletak di tangan Badan Pertanahan Nasional (BPN). Fakta ini berimplikasi pada pada munculnya berbagai konflik yang melibatkan Kementerian Kehutanan dan Badan Pertanahan Nasional (BPN) dalam menentukan lahan hutan dan non-hutan. Hal ini meliputi perselisihan mengenai kawasan pertanian di dalam dan di luar kawasan hutan hingga kepastian hukum pengakuan penguasaan tanah oleh masyarakat adat.

Penetapan kawasan hutan berada di Kementerian Kehutanan, sesuai Peraturan Pemerintah No. 44 Tahun 2004. Namun, UU No. 5 Tahun 1960 tentang Pokok Agraria (UUPA) pasal 19 mementahkan Peraturan Pemerintah tersebut. UU No 5 menyebutkan bahwa pendaftaran tanah (kawasan hutan - non hutan) hanya diselenggarakan oleh BPN. Selain itu,

\footnotetext{
${ }^{43}$ Mardiastuti, Ani, 2012, The Role Of UN-REDD In The Development of REDD+ In Indonesia Volume III: Highlights Of REDD+ Related Projects In Indonesia, Jakarta, Indonesia: Indonesia Ministry of Forestry
}

Pasal 2 ayat 4 dalam UUPA memberikan dasar hukum bagi instansi pemerintah terkait dengan tanah ulayat atau tanah adat, di mana pemerintah dapat mendelegasikan kekuasaan penguasaan tanah kepada masyarakat hukum adat selama tidak bertentangan dengan kepentingan nasional.

Praktek dualisme ini memberikan beban tambahan kepada Kementerian Kehutanan sekaligus memperumit administrasi pertanahan di Indonesia. Kementerian Kehutanan hanya diberikan hak mengurus tanah yang dimasukkan dalam kategori kawasan hutan. Kondisi ini membatasi kewenangan Kementerian Kehutanan dalam mengelola lahan-lahan yang dianggap berada di luar kawasan hutan, yang notabene menjadi kewenangan BPN. Lebih lanjut, pengelolaan APL kini berada di tangan Pemerintah Daerah.

Kementerian Kehutanan juga menunjuk dirinya sendiri sebagai pihak yang berwenang atas izin proyek REDD+. Penunjukan yang bersifat egosentris ini dijustifikasikan oleh fakta bahwa $70 \%$ dari luas daratan Indonesia berada di bawah kewenangan Kementerian Kehutanan. ${ }^{44}$ Kementerian Kehutanan mengkoordinir proyek REDD+ sukarela dan proyekproyek percontohan di bawah Permenhut No. P.68/Menhut-II/2008 serta izin pemanfaatan karbon pada hutan produksi

\footnotetext{
${ }^{44}$ Masripatin, Nur, 2010, Strategi REDD Indonesia.
} 
dan hutan lindung melalui Permenhut No. P.36/Menhut-II/2009.

Setelah adanya LoI antara Pemeruntah Indonesia dan Norwegia, Satgas REDD+ dibentuk secara independen oleh Presiden SBY di luar Kementerian Kehutanan. Instansi ini memiliki tugas untuk memonitor langsung implementasi perjanjian LoI serta menyiapkan lembaga REDD+ di tanah air. Satgas REDD+ menyusun Strategi Nasional REDD+ mulai bulan Juni 2012. ${ }^{45}$ Tiga lembaga baru akan dibentuk sebagai lembaga resmi pengurus REDD+ nasional yakni Badan REDD+ (BP REDD+) yang akhirnya didirikan tahun 2013, Instrumen pendanaan REDD+ dan Pelaporan dan Verifikasi REDD+. Pendirian badan REDD+ nasional ini dinilai sudah terlambat, jika menilik antusiasme pemerintah Indonesia melaksanakan REDD+ sejak Rencana Aksi Bali 2007.

Di antara dua lembaga yang saling mengklaim kepemilikan wewenang pelaksanaan REDD+ di Indonesia, sebenarnya terdapat friksi. Kementerian Kehutanan menghendaki Satgas REDD+ berada di bawah Kementerian Kehutanan. ${ }^{46}$ Sedangkan, Satgas REDD+ menolak karena menganggap lembaga

\footnotetext{
${ }^{45}$ Huber, Suzy, 2013, Op.Cit., hlm 3

${ }^{46}$ Society of Indonesian Environmental Journalists, 2013, Satgas REDD+ Dan Kementerian Kehutanan Berebut Kewenangan, May 20, 2015. http://www.siej.or.id/?w=article \&nid $=450$
}

independen diperlukan untuk mengurus hutan karena Kementerian Kehutanan dinilai telah gagal mengelola hutan. Kementerian Kehutanan merespon dengan menyatakan bahwa kehadiran Satgas REDD+ justru akan menambah kegagalan tersebut.

Yang tidak kalah menarik adalah masalah penyusunan tahapan implementasi REDD+ di Indonesia. Tahapan implementasi REDD+ yang dikeluarkan oleh Kementerian Kehutanan berbeda dengan tahapan milik Satgas REDD+. Dualisme lembaga dengan kewenangan implementasi REDD+ ini juga membingungkan dan tumpang tindih karena target waktu persiapan, transisi dan implementasi berbeda dengan pencapaian yang berbeda pula.

\section{d. Kontestasi Antar Lembaga}

\section{Pemerintah Pusat dan Daerah}

Kontestasi pusat-daerah merupakan perselisihan antara pemerintah pusat dan pemerintah daerah mengenai kewenangan dan kekuasaan untuk mengatur sumber daya alam. Hal ini berkaitan erat dengan siapa yang berhak mengelola serta menerima manfaatnya. Kontestasi semacam ini di Indonesia banyak terjadi dan berdampak bagi pelaksanaan proyek seperti REDD+. Pemerintah pusat dan Pemerintah Aceh mengalami hal yang sama ketika proyek Ulu Masen tengah disiapkan dan dijalankan. 
Desentralisasi politik pasca jatuhnya Soeharto di era reformasi memberikan kesempatan kepada daerah untuk mengelola pemerintahannya. Namun, undang-undang tentang desentralisasi politik dan pengaturan kehutanan yang tumpang tindih membuka peluang terhadap penafsiran yang berbeda. Pengertian masing-masing pihak yang berbeda merupakan penyebab mendasar dari perselisihan kewenangan antara pusat dan daerah.

UU No. 22/1999 dan UU No. 41/1999 memiliki kesenjangan kebijakan yang menciptakan suatu kondisi pengelolaan sumber daya alam dalam ketidakpastian. UU No. 22/1999 digunakan Pemerintah Daerah sebagai landasan legal yang menjamin legitimasi Pemerintah Daerah untuk mengelola sumber daya alam mereka di daerahnya sendiri. Undangundang ini pada prinsipnya mengakui keberagaman daerah dan hak bagi daerah untuk mengelola sumber daya alam di wilayahnya. $^{47}$

Di lain pihak, UU No. 41/1999 merupakan senjata politik pemerintah pusat untuk memiliki kewenangan atas pengelolaan sumber daya alam di seluruh Indonesia. Berdasarkan UU ini, maka

\footnotetext{
${ }^{47}$ Wollenberg, Eva, et.al, 2009, Antara Negara dan Masyarakat: Desentralisasi di Indonesia, dalam Moira Moeliono, et.al (Eds), Desentralisasi Tata Kelola Hutan: Politik, Ekonomi dan Perjuangan untuk Menguasai Hutan di Kalimantan, Indonesia, Bogor, Indonesia: CIFOR, hlm 8
}

pemanfaatan sumber daya alam, termasuk hutan, konservasi sumber daya alam dan pembuatan standarisasi masih merupakan tanggungjawab pemerintah pusat. ${ }^{48}$

UU yang juga memanaskan hubungan pusat-daerah adalah Peraturan Pemerintah No. 34/2002 tentang tata hutan dan penyusunan rencana pengelolaan hutan. UU ini diterbitkan untuk menanggapi tidak terkendalinya eksploitasi kayu dan tuntutan pemerintah kabupaten atas pendapatan dari pengelolaan kayu yang dibenarkan dan diperbolehkan oleh Surat Keputusan Menteri No. 05.1 Tahun 2000. ${ }^{49}$ Dari perspektif Pemerintah Daerah, UU yang membatasi pemberian izin konsesi hutan skala kecil ini dilihat sebagai upaya resentralisasi kewenangan yang mempertahankan dominasi pusat dalam mengelola sumber daya nasional.

Selain dua undang-undang di atas yang saling tumpang tindih dan bertentangan, dalam kasus Aceh terdapat UU lainnya yang juga tergolong unik sekaligus menambah kepelikan. Setelah tsunami dan adanya perjanjian perdamaian antara GAM dan Pemerintah Indonesia, Aceh diberikan hak prerogatif untuk mengatur sumber daya alam yang dimilikinya. Hak ini memberikan suatu dasar hukum dan politik yang kuat bagi

\footnotetext{
${ }^{48}$ Siswanto, Wandojo dan Wahjudi Wardojo, 2006, Desentralisasi Sektor Kehutanan: Pengalaman Indonesia, Bogor, Indonesia: CIFOR, hlm 180 ${ }^{49}$ Wollenberg, Eva, et.al., 2009, Op.Cit., hlm 17
} 
pemerintah Aceh untuk mengatur sektor kehutanannya.

Kekuatan legal ini diperoleh melalui Undang-Undang No. 11 Tahun 2006 tentang Pemerintahan Aceh, yang sering disebut sebagai Otonomi Khusus Aceh. UU ini memberikan pemerintah provinsi Aceh suatu kewenangan untuk mengendalikan sumber daya alamnya dan memiliki pendapatan dari kegiatan kehutanan sebesar $80 \% .^{50}$ Dengan demikian, jika menyangkut REDD+, pemerintah Aceh berhak secara mandiri mengadakan proyek tanpa harus merujuk pada kewenangan pemerintah pusat. Apalagi, pendekatan REDD+ global menawarkan suatu pendekatan subnasional atau proyek.

Sebaliknya, pemerintah pusat menyatakan bahwa mereka berhak mengelola regulasi terkait konvensi internasional semacam UNFCCC serta mengatur standar dan prosedur hasil konvensi ke dalam kebijakan nasional yang harus dipatuhi pemerintah lokal. ${ }^{51} \mathrm{Hal}$ ini dikonfirmasi oleh Dedek Hadi, pejabat Dinas Kehutanan Aceh yang termasuk dalam Task Force REDD+ Ulu Masen.

\footnotetext{
${ }^{50}$ Clarke, Ross Andrew, 2010, Moving The REDD Debate From Theory To Practice: Lesson Learned From The Ulu Masen Project, Law, Environment and Development Journal, 6(1), 36-61, hlm 53 ${ }^{51}$ Smith, J, et.al., 2007, Illegal Logging, Collusive Corruption and Fragmented Governments in Kalimantan, Indonesia, dalam L. Tacconi (Ed), Illegal Logging: Law Enforcement, Livelihoods and the Timber Trade, London, UK: Earthscan
}

Pusat dianggap tidak memberikan restu pada proyek percontohan Ulu Masen. Proyek ini dianggap melangkahi wewenang pusat yang menjadi pemegang kuasa utama.

Perebutan kewenangan berujung pada perebutan status kepemilikan REDD+ Ulu Masen. Penerbitan izin pengelolaan REDD+ dan stok karbon hanya dapat dikeluarkan Kementerian Kehutanan dan kerjasama kontraktual Pemerintah Daerah dengan aktor internasional harus disetujui oleh pemerintah pusat. Kekuatan pemerintah untuk mengatur dan mengelola proyek REDD+ didukung oleh UU sebagai berikut: ${ }^{52}$

- UU No

$41 / 1999$

kewenangan

pusat

mengelola sumber daya

alam di seluruh Indonesia

- Peraturan Pemerintah No. $6 / 2007$ mengenai pembentukan suatu pengelolaan hutan serta perincian persyaratan pengelolaan

- Peraturan Presiden Republik Indonesia No. 46/2008 terkait tugas dan pembentukan Dewan

\footnotetext{
${ }^{52}$ McCulloch, Lesley, 2010, Ulu Masen REDD Demonstration Project: The Challenges of Tackling Market Policy and Governances Failures that Underlie Deforestation and Forest Degradation, Intitute for Global Environmental Strategies, hlm 18
} 
Nasional Perubahan Iklim (DNPI)

- Peraturan

Menteri

Kehutanan No. P.68/2008

tentang implementasi

aktivitas Demonstration

Activities REDD (DAREDD)

- Peraturan

Menteri

Kehutanan

No.

P.30/Menhut-II/2009

tentang hal-hal prosedural REDD

- Peraturan

Menteri

Kehutanan No. P.36/2009 di mana Kemenhut memiliki kewenangan untuk memberikan lisensi-lisensi proyek REDD+ di Indonesia

Dengan landasan tersebut, pemerintah pusat tidak tinggal diam terhadap keberadaan proyek REDD+ Ulu Masen. Berdasarkan UU tersebut, pemerintah pusat berhak memiliki andil dan turut serta dalam proyek. Mereka juga menganggap bahwa pemerintah pusat berhak memberikan lisensi pengelolaan stok karbon Ulu Masen. Pemerintah pusat juga berpendapat bahwa Pemerintah Daerah Aceh telah merendahkan hukum Indonesia, yakni bahwa sebenarnya pemerintah Aceh tidak bisa menandatangani kontrak dengan aktor internasional secara langsung. Pemda Aceh harus mendapatkan persetujuan terlebih dahulu dari Menteri Dalam Negeri dan Menteri Luar Negeri. ${ }^{53}$

Di sisi lain, melalui UU No. 11/2006 Pemerintah Daerah Aceh menegaskan kewenangan Pemda Aceh dalam pengelolaan sumber daya alam yang berada di wilayah Aceh. Oleh karena itu, Pemerintah Daerah Aceh tidak perlu meminta persetujuan pusat mengenai pelaksanaan proyek REDD+ Ulu Masen serta perjanjian kontraktual dengan investor-investor asing. Untuk menguatkan hak kepemilikan REDD+ Ulu Masen, Gubernur Irwandi Yusuf akhirnya mengeluarkan Surat Keputusan (SK) Gubernur No. 522/372/2009 yang membentuk Satuan Tugas REDD+ Aceh. ${ }^{54}$

Undang-undang yang bertabrakan dalam masalah tenurial antara pusat dan daerah juga menghambat pengambilan kebijakan pemanfaatan lahan yang optimal dan adil. Bersamaan dengan perselisihan kepemilikan REDD+ Ulu Masen dan karbonnya, permasalahan pemanfaatan lahan dibiarkan begitu saja. Pembiaran seperti ini menimbulkan konflik tenurial yang terjadi di antara pemerintah dengan

\footnotetext{
${ }^{53}$ Eye on Aceh Interview with Retno Maryani, Indonesian Government Delegation to World Forestry Congress, Buenos Aires, Interviewed 24 Oktober 2009.

${ }^{54}$ McCulloh, Lesley, 2010, Op.Cit.,
} 
masyarakat, pemerintah dengan swasta, dan masyarakat dengan swasta.

Berdasarkan daftar klasifikasi legal kawasan Ulu Masen yang dikeluarkan oleh Keputusan Kementerian Kehutanan No. 170/KPTS-II/2000 menunjukkan bahwa $58 \%$ kawasan hutan di dalam area proyek tidak mendapat status perlindungan yang kuat. Hal tersebut memungkinkan hutan dieksploitasi oleh pihak pemerintah, masyarakat dan swasta sesuai dengan kepentingan masing-masing. Akibatnya terjadi konflik tenurial yang pada umumnya hanya memarginalisasikan masyarakat adat sehingga semakin sulit memanfaatkan hasil hutan.

Meskipun Gubernur Irwandi Yusuf telah mengeluarkan moratorium logging untuk memberhentikan pembalakan, izin konsensi penebangan industri bagi selusinan perusahaan-perusahaan untuk beroperasi di Aceh yang dikeluarkan tahun 1990-an masih berlaku. ${ }^{55}$ Hal ini sesuai dengan aturan yang telah diterbitkan Kementerian Kehutanan. Dengan demikian, setiap proposal REDD+ di Aceh harus berasal dari dan memberikan kompensasi bagi para pemegang konsesi tersebut.

Luas konsesi yang diberikan pemerintah pusat mencapai separuh dari rencana luasan proyek sebesar 750,000 ha

\footnotetext{
${ }^{55}$ Forest People Programme, 2011, Op.Cit., hlm 2
}

di Ulu Masen. Konsesi ini tidak aktif karena kebijakan moratorium logging yang memberhentikan aktivitas Hak Pengusahaan Hutan (HPH). Permasalahannya, kebijakan moratorium logging Pemerintah Daerah Aceh memiliki kelemahan. Kebijakan ini tidak menghapus HPH melainkan hanya memberikan jeda tebang HPH untuk sementara. Artinya HPH dapat diaktifkan kembali melalui Kementerian Kehutanan. Beberapa perusahaan konsesi yang telah habis masa berlaku izinnya, ternyata diperpanjang izinnya oleh pemerintah pusat tanpa sepengetahuan Pemerintah Daerah. ${ }^{56}$

\section{Level Sub-Nasional}

Pada level sub-nasional, terdapat berbagai aktor yang memiliki fungsi dan peranan yang berbeda dalam tata kelola proyek. Mereka merupakan pihak pengelola proyek yang terdiri dari aktor publik maupun privat, dari Pemerintah Daerah Aceh, NGO internasional FFI hingga perusahaan pialang karbon CC.

Di sisi lain, ada pula masyarakat adat yang menjadi smallholders yang seharusnya dilibatkan sekaligus terpengaruh dengan keberadaan proyek REDD+ Ulu Masen. Masing-masing aktor pada level horizontal seharusnya mampu menjalankan fungsinya dalam proyek.

\footnotetext{
${ }^{56}$ Wawancara dengan anggota Task Force REDD+ Aceh, Dedek Hadi, 24 April 2015
} 
Dalam hal ini, kemampuan serta akuntabilitas aktor pengelola menjadi sangat penting.

Sasaran utama dari para pelaku adalah adanya kerjasama, partisipasi lokal serta adanya trust diantara mereka sehingga tujuan kolektif tercapai. Tujuan kolektif dari adanya proyek REDD+ Ulu Masen adalah menghasilkan kredit karbon serta mengurangi pembalakan liar di 6 kabupaten, yakni sekitar 750.000 ha kawasan hutan. Selain itu, targetnya adalah proyek ini akan diintegrasikan ke dalam proyek nasional setelah tahun 2012 .

Akan tetapi, masing-masing aktor ternyata memiliki kepentingan yang berbeda tanpa memiliki pemahaman yang sama mengenai REDD+ secara umum maupun proyek REDD+ Ulu Masen secara khusus. Terjadi kontestasi di antara mereka yang menimbulkan berbagai permasalahan.

\section{a. Kapabilitas dan Akuntabilitas} Pengelola Proyek

Kapabilitas berkaitan dengan kemampuan pengelola proyek dalam menjalankan fungsinya sebagaimana yang tertera dalam dokumen perencanaan tata kelola proyek. Sedangkan, akuntabilitas berkaitan dengan sejauh mana kinerja atau usaha yang dilakukan dapat diaudit atau dijelaskan kepada publik secara bertanggungjawab.
Dalam pelaksanaan REDD+ Ulu Masen di Aceh, awalnyan kemampuan pengelola proyek meyakinkan namun dalam perjalanannya ditemukan bahwa terjadi kesulitan dalam menerjemahkan mekanisme REDD+ dalam teori ke dalam pelaksanaan di lapangan. Terlebih lagi, akuntabilitas mereka tidak dapat dicek dan dikontrol oleh publik secara luas khususnya oleh masyarakat adat.

Salah satu prasyarat dari pelaksanaan REDD+ adalah SDM yang kompeten. Namun Pemerintah Daerah Aceh ternyata kurang paham soal kepemilikan tanah, hak karbon dan skema pendanaan. Kurangnya pemahaman menyebabkan pemerintah sulit terbuka dalam mendiseminasi semua informasiinformasi relevan dan penting yang berhubungan dengan proyek REDD+ untuk masyarakat sekitar dan pemangku kepentingan tingkat tapak.

Pada tahun 2007 hingga 2010 ketika akhirnya implementasi REDD+ mulai dilaksanakan, aturan internasional memang belum final dan masih banyak ketidakpastian, termasuk pasar karbon. Akibatnya Pemerintah Daerah Aceh semakin kesulitan menerjemahkan teori menjadi praktek karena mereka awam dan masih meraba-raba ${ }^{57}$. Namun, sikap konfidensial pemerintah Aceh akibat 
kurang pemahaman ini justru akhirnya menimbulkan kecurigaan dan prasangka yang menyebabkan konflik dengan masyarakat adat terkait manfaat REDD+.

Pihak kedua, yakni perusahaan pialang karbon Carbon Conservation tidak dikenal secara luas dalam proyek REDD+ Ulu Masen, terutama bagi masyarakat umum. Beberapa kali menanyakan hal yang sama kepada para kepala mukim yang selalu turut serta dalam sosialisasi awal perencanaan poryek, mereka mengaku tidak pernah tahu apa dan siapa Carbon Conservation. ${ }^{58}$ Informasi yang beredar di masyarakat adat justru bahwa pendanaan ini berasal dari Norwegia, bukan melalui Carbon Conservation.

Carbon Conservation berhasil menarik Merrill Lynch untuk membeli hasil carbon offset sebesar US\$ 9 juta. Namun ketika akhirnya Merrill Lynch diakuisisi oleh Bank of America akibat krisis ekonomi global 2008, dana yang dijanjikan menjadi tidak jelas. Apakah dana tersebut sudah turun sebelumnya atau justru tidak turun akibat akuisisi tidak dapat dikonfirmasi.

Christopher Lang pernah mencoba menghubungi Carbon Conservation, namun tidak berbalas. Dari hasil wawancara surel yang berhasil dilakukan penulis dengan Lang, ia menyatakan bahwa persoalan dana yang dijanjikan Carbon Conservation dalam pembayaran karbon oleh Merrill Lynch tidak dapat dipastikan. $^{59}$

“In 2008, Merrill Lynch promised to buy US\$ 9 million worth of carbon credits from Ulu Masen. I understand that no carbon credits were ever generated from the Ulu Masen Project. In 2013, I asked Dorjee Sun whether Merrill Lynch actually paid any money towards the project, and what the status of the agreement with Merrill Lynch was. Sun did not reply to my questions. Merrill Lynch didn't go bankrupt, but sold itself to Bank of America for about US\$ 50 billion (see this 2008 article in NY Times). Bank of America Merrill Lynch still exists as the corporate and investing division of Bank of America." 
Meskipun tidak berkaitan langsung dengan masalah proyek REDD+ Ulu Masen, selama ini CC banyak bekerjasama dengan perusahaan tambang. Di Brazil, CC menggandeng Rio Tinto ${ }^{60}$ dan dalam proyek di Kalimantan, bekerjasama dengan APP anak perusahaan Sinarmas. ${ }^{61}$ Mungkin tidak terlalu terkait dengan REDD+ Ulu Masen, namun hal-hal tersebut yang membuat CC dianggap tidak akuntabel dalam menjalankan proyek.

Dari hasil pertemuan dengan beberapa kepala mukim yang terlibat langsung, yang dilakukan pada bulan April 2015, ditemukan ada beberapa permasalahan yang dipertanyakan masyarakat adat maupun LSM lokal terkait pihak ketiga yakni FFI. Permasalahan berkaitan dengan pengutusan FFI sebagai pihak fasilitator hingga dana yang dipakai untuk sosialisasi. ${ }^{62}$ Menurut LSM Jaringan Komunitas Masyarakat Adat Aceh (JKMA) dan para tetua adat, FFI bukanlah pihak yang melakukan sosialisasi secara langsung melainkan hanya fasilitator. Fasilitas yang diberikan berbentuk pertemuan-pertemuan di hotel-hotel besar, mengundang pihak-pihak asing, tetua adat hingga instansi Pemerintah Daerah Aceh.

${ }^{60}$ Carbon Conservation, 2006

${ }^{61}$ Business Wire, 2010, Audit of How Sinarmas is Pulping the Planet, Melbourne: ITS Global ${ }^{62}$ Wawancara dengan Anwar Ibrahim, Kepala Mukim Teunom, Calang, Aceh Jaya, 23 April 2015
Faktor pemilihan FFI sebagai mitra kemudian akhirnya menimbulkan kecurigaan, yakni berdasarkan faktor kedekatan dengan Irwandi Yusuf. Sebagai seorang mantan pejuang GAM dan dokter hewan terlatih di Amerika, Irwandi Yusuf pernah bergabung dengan FFI dan mendirikan FFI-Aceh. ${ }^{63}$ Dalam proyek AFEP yang mendukung langkah Green Visions Irwandi, FFI juga merupakan salah satu lembaga yang mendapatkan dana dari Bank Dunia selain Yayasan Leuser Internasional (YLI).

Tidak dijelaskan secara mendetail dan terbuka kemitraan yang dijalankan oleh pemda Aceh dengan FFI. Yang diketahui publik hanyalah bahwa FFI memang sudah lama membantu Gubernur Irwandi dalam mewujudkan Aceh Green yang menjadi misi utama pemerintahannya. ${ }^{64}$

FFI juga dinilai tidak melakukan sosialisasi secara keseluruhan kepada seluruh imeum mukim. ${ }^{65}$ Dari pengakuan beberapa kepala mukim yang telah ikut serta dalam berbagai pertemuan, dari total 61 mukim yang ada, hanya tiga hingga lima mukim yang terlibat. Sisanya tidak pernah diikutsertakan karena yang ikut

\footnotetext{
${ }^{63}$ O’Niles, John , 2007, It's Not Easy Being Green in Aceh, Indonesia, Forest Carbon Portal, October 25, 2007, http://www.forestcarbonportal.com/news/its-noteasy-being-green-aceh-indonesia ${ }^{64}$ Wawancara dengan Zulfikar Arma, Badan Pelaksana JKMA Banda Aceh, Aceh, 21 April 2015 ${ }^{65}$ Imeum mukim adalah kepala mukim
} 
hanya mukim-mukim yang itu-itu saja. Contohnya adalah Anwar Ibrahim yang sudah 31 kali ikut pertemuan. ${ }^{66}$

\section{b. Sinergitas Pelaksanaan Proyek}

Lembaga riset CIFOR menunjukkan bahwa keberhasilan implementasi mekanisme REDD+ salah satunya ditentukan oleh azas partisipatoris dan sinergitas, di mana semua pelaku diberikan kesempatan yang sama untuk melaksanakan program. ${ }^{67}$ Bahkan pelaku paling lemah, dalam banyak kasus adalah masyarakat adat harus diikutsertakan dalam mekanisme tersebut secara adil. Tidak ada satu pihak pun yang ditinggalkan.

Cakupan tanggungjawab pemerintah Aceh dalam proyek Ulu Masen adalah bertanggungjawab untuk keseluruhan pengendalian, manajemen dan supervisi proyek, memimpin mitra untuk mengembangkan rencana spasial dan hukum provinsial yang mendukung, implementasi pengendalian pembalakan liar, bekerjasama dengan pemerintah pusat dan pemerintah Aceh melalui badannya yakni Task Force REDD+ Aceh, ternyata tidak pernah melakukan check and balance terhadap sosialisasi dan capacity building yang dilakukan oleh mitranya, FFI.

\footnotetext{
${ }^{66}$ Wawancara dengan Sabee Basyah, Kepala Mukim Geumpang, Pidie, 22 April 2015 dan Wawancara dengan Anwar Ibrahim, Kepala Mukim Teunom, Calang, Aceh Jaya, 23 April 2015 ${ }^{67}$ CIFOR, 2012
}

Pemerintah Aceh seolah melepaskan tangan dari kewajiban untuk selalu melakukan pengelolaan berkelanjutan Ulu Masen. ${ }^{68}$

Berdasarkan hasil wawancara dengan masyarakat adat, baik di Aceh Jaya, Pidie dan Aceh Besar ditemukan bahwa Pemerintah Daerah Aceh tidak berpartisipasi dalam proyek. Anggota Task Force REDD+ Aceh juga menegaskan bahwa memang pemerintah Aceh tidak pernah terjun dalam proyek secara langsung. Semuanya diserahkan dan dilakukan oleh FFI. Menurutnya, bukan ranah pemda untuk melakukan hal tersebut Masyarakat adat tidak mendapatkan informasi dari pihak Pemerintah Daerah. Pemerintah Aceh juga tidak pernah memberikan perhatian khusus terkait dengan penghidupan masyarakat adat yang dipengaruhi oleh proyek REDD+. Hanya satu kali di awal proyek, ketika Gubernur Irwandi Yusuf mengumpulkan para tetua mukim dalam sebuah pertemuan.

Di pihak lain, sebagai mitra pemerintah, FFI sebenarnya berfungsi menjadi fasilitator yang akan memberikan pelatihan baik pada anggota pemerintah Aceh dalam Task Force REDD+ maupun masyarakat adat. Namun, staf FFI sendiri hanya tahu sedikit soal REDD+ karena

\footnotetext{
${ }^{68}$ The Provincial Government of Nangroe Aceh Darusslam, 2007, The Triple Benefit Project Design Note for CCBA Audit. The Provincial Government of Nangroe Aceh Darussalam, hlm 46-47
} 
mereka ternyata tidak dilibatkan dalam perencanaan desain proyek pada tahun 2007. ${ }^{69}$ Hal ini menimbulkan keraguan dan juga pertanyaan sejauh mana komunitas masyarakat adat memahami REDD+ dan dampaknya bagi kehidupan mereka ketika pihak yang seharusnya menjadi mentor justru tidak menguasai permasalahan.

Pemaparan mengenai proyek juga dijelaskan dalam bahasa yang sulit dimengerti, dokumen dituliskan dalam bahasa inggris sehingga masyarakat sulit memahami. Hal ini menyebabkan ketidakefektifan proses pertemuan dengan kepala mukim. Ketidakpahaman kepala mukim akhirnya menyebabkan ketidakmampuan dalam menjelaskan proyek kepada warganya di puluhan gampong.

Dua hal tersebut akhirnya menyebabkan masyarakat adat di Aceh tersingkirkan dalam proses partisipasi. Sebenarnya, masalah ini sudah teridentifikasi pada audit CCBA yang menunjukkan bahwa proyek Ulu Masen tidak memenuhi kriteria "best practice" dalam melibatkan partisipasi komunitas lokal. $^{70}$

\begin{tabular}{rrr}
\multicolumn{2}{c}{ Terdapat indikasi } & bahwa \\
masyarakat adat dilihat sebagai
\end{tabular}

\footnotetext{
${ }^{69}$ Wawancara Chris Lang dengan Goran Eklof, The Swedish Society for Nature Conservation, Februri 2013

${ }^{70}$ McCulloch, Lesley, 2010, Op.Cit.,
}

penghambat proyek sehingga tidak banyak informasi yang diberikan kepada mereka. ${ }^{71}$ Para kepala mukim yang diwawancara menyatakan bahwa tidak ada tugas khusus yang diberikan pengelola proyek kepada mereka. Padahal melibatkan masyarakat adat setempat merupakan salah satu kunci keberhasilan proyek, terutama di mana para pengelola dapat memantau dan mendistribusikan informasi tentang proyek hingga keikutsertaan masyarakat.

Masyarakat adat juga buta terkait zonasi proyek Ulu Masen ataupun peta spesifik proyek, misalnya terkait luas batas zona serta zona apa saja yang termasuk dalam luasan proyek 750.000 ha, apakah zona hutan saja atau termasuk juga pemukiman. $^{72}$ Dengan demikian, masyarakat adat yang tidak mengetahui sejauh mana batas pengambilan hasil hutan maupun kayu berdasarkan pengelolaan hukum adat yang berlaku. Akibatnya, ketika mereka menganggap mengambil hasil hutan dalam wilayah lahan, mereka dituduh melakukan pembalakan liar.

Minimnya partisipasi masyarakat menyebabkan mereka tidak mendukung adanya proyek. Meski tidak terangterangan, mereka enggan dengan adanya

\footnotetext{
${ }^{71}$ Rathgeber, Theodor, 2009, Climate Change Violates Human Rights, Heinrich Boell Stiftung, 6, hlm 27

${ }^{72}$ Wawancara dengan Zulfikar Arma, Badan Pelaksana JKMA Aceh, 22 April 2015
} 
kehadiran proyek yang memotong mata pencaharian. Mereka juga tidak senang dituduh sebagai pembalak liar, ketika perusahaan besar yang membalak secara liar tidak ditindak aparat pemerintah.

\section{c. Transparansi Proyek}

Transparansi adalah di mana semua pihak yang terlibat dalam program diberikan tanggungjawab pengelolaan yang setara, termasuk dalam distribusi manfaat yang dihasilkan. Dengan adanya transparansi, pengelolaan proyek dapat dipertanggungjawabkan kepada publik, khususnya masyarakat yang terkena langsung dampak proyek.

Hasil wawancara dengan penduduk mukim yang tinggal di kawasan proyek Ulu Masen menunjukkan adanya ketidakjelasan terkait proyek REDD+ Ulu Masen di mana masyarakat adat sendiri merasa dikucilkan. Hal ini menunjukkan ketiadaan transparansi dalam proyek REDD+ Ulu Masen. Ketidakjelasan tersebut meliputi masalah kepemilikan dan pengelolaan, pendanaan dan manfaat, aktivitas proyek dan penghitungan karbon.

Masalah kepemilikan proyek menjadi polemik di tengah masyarakat. Jika merujuk pada dokumen perencanaan proyek, seharusnya pemilik utama proyek adalah pemerintah Aceh di mana dua aktor lain adalah mitra pemerintah Aceh. Akan tetapi praktek di lapangan berkata lain. Pemerintah Aceh menyatakan bahwa proyek berada di bawah kuasa FFI, pemerintah Aceh hanya menjadi aktor yang menyediakan regulasi serta mengadakan moratorium logging untuk menunjang pelaksanaan proyek Ulu Masen. ${ }^{73}$ Di lain pihak, karena sosialisasi semuanya dilakukan oleh FFI, masyarakat beranggapan bahwa proyek ini adalah proyek buatan FFI.

Berkaitan dengan pendanaan proyek, informasi yang dibuka kepada publik juga minim. Dalam dokumen yang dikeluarkan oleh Pemerintah Daerah Aceh dituliskan bahwa pendanaan akan diperoleh ketika kredit karbon telah berhasil dijual kepada Merrill Lynch selaku perusahaan yang bekerjasama dengan CC. ${ }^{74}$ Namun, tidak diketahui secara jelas mengenai aliran dana serta sumber dana proyek.

Selain itu, masalah manfaat dari proyek juga tidak dijelaskan dengan gamblang. Masyarakat adat sama sekali tidak mengetahui kira-kira apa manfaat yang akan mereka terima dengan adanya proyek REDD+. Mereka tidak dijelaskan dalam bentuk apa insentif dari REDD+ akan diberikan kepada mereka. ${ }^{75}$

Terakhir, aktivitas proyek berkenaan dengan sejauh mana program-

\footnotetext{
${ }^{73}$ Wawancara dengan Dedek Hadi, Anggota Taks Force REDD+ Aceh, Dinas Kehutanan Aceh, Banda Aceh, 24 April 2015

${ }^{74}$ Government of Aceh, 2008

${ }^{75}$ Wawancara Yayasan Rumpun Bambu dengan Nas, Kepala Mukim Lam Leu Ot, Oktober 2011
} 
program yang telah direncanakan dijalankan. Kegiatan konservasi hutan serta penghitungan karbon hasil konservasi seharusnya dipublikasikan pula kepada seluruh stakeholder yang terlibat di dalamnya. Masyarakat adat menjelaskan bahwa sama sekali tidak mengetahui sejauh mana program dalam proyek sudah berjalan. $^{76}$

d. Proses FPIC Tidak Berjalan dan Kegagalan Konsolidasi Masyarakat Adat

Pada masa awal akan dimulainya implementasi proyek, bersama mitra FFI dan CC, Gubernur Irwandi menegaskan bahwa ia tidak menginginkan proyek berjalan tanpa adanya informasi yang lengkap bagi masyarakat. ${ }^{77}$ Saat itu, perencanaan pra-implementasi, yang meliputi desain, dana hingga audit proyek telah selesai dilaksanakan. Implementasi hanya tinggal menunggu waktu untuk dilaksanakan.

Dengan sudah adanya proyek berarti masyarakat adat tidak dilibatkan dalam memahami proses konseptual program REDD+, penaksiran dampak, manfaat hingga output sebelum perencanaan hingga pada masa perencanaan. Sayangnya hal ini juga terjadi karena Ulu Masen diaudit melalui standar

\footnotetext{
${ }^{76}$ Wawancara dengan Anwar Ibrahim, Kepala Mukim Teunom, Calang, Aceh Jaya, 23 April 2015 ${ }^{77}$ McCulloh, Lesley, 2010, Op.Cit.,
}

CCB tahap awal yang tidak menyertakan FPIC. Baru kemudian di 2009, melalui audit kedua, FPIC diwajibkan.

Masalah terlambat atau tidaknya pelaksanaan FPIC bukan masalah utama. Masalah terbesar adalah bahwa pelaksanaan FPIC ini tidak merata dan tidak berjalan sebagaimana mestinya. FFI memang telah memfasilitasi berbagai pertemuan yang mengikutsertakan mukim untuk menginformasikan mereka terkait FPIC proyek REDD+ Ulu Masen. Hal ini diakui oleh beberapa kepala mukim yang memang diundang dalam pertemuan.

Dalam perencanaan FPIC terdapat 61 mukim yang harus diundang, ternyata praktek di lapangan tidak demikian."FPIC tidak ada di Aceh, FPIC tidak pernah dilaksanakan 100\%. Ada banyak dokumen tentang REDD tapi tidak semua saya tahu dan ikut prosesnya. REDD jalan terlebih dahulu, FPIC menyusul kemudian. "78

Dari total 61 mukim yang terdaftar, kurang lebih hanya beberapa saja yang dilibatkan dalam proses FPIC ini, seperti Mukim Teunom, Geumpang, Siem. Jika tidak semua mukim dilibatkan, bagaimana masyarakat adat di seluruh wilayah kawasan REDD+ Ulu Masen dapat

\footnotetext{
${ }^{78}$ Wawancara dengan Anwar Ibrahim, Sabee Basyah, Ibrahim, Zulfikar Arma, Mirwandah, April 2015
} 
mengetahui proyek REDD+ akan dijalankan di wilayah hutan mereka. ${ }^{79}$

e. Pengagunan Hutan Aceh oleh CC kepada East-Asia Minerals

Pada Mei 2011, perusahaan tambang Kanada, East-Asia Minerals menandatangani Memorandum of Understanding (MoU) dengan Carbon Consevation. MoU tersebut berisi kesepakatan pembelian $50 \%$ saham perusahaan CC. ${ }^{80}$ Di bawah MoU tersebut, East-Asia Minerals akan membayar tunai uang sebesar US\$ 500 ribu serta menerbitkan 2.5 juta lembar saham bagi CC. ${ }^{81}$ Kehadiran East-Asia Minerals tersebut menandakan bahwa secara tidak langsung, Carbon Conservation mundur dari pengelolaan proyek Ulu Masen.

Kepentingan East-Asia Minerals di Ulu Masen adalah operasi pertambangan emas seluas 6000 ha di tengah-tengah

\footnotetext{
${ }^{79}$ Wawancara dengan Anwar Ibrahim, Kepala Mukim Teunom, Calang, Aceh Jaya, 23 April 2015 ${ }^{80}$ Lang, Christopher, 2013, Canadian Mining Company East Asia Minerals Is "Working Closely" With Indonesian Government Officials To Destroy Aceh's Forests, REDD-Monitor. April 24, 2015, http://www.redd-monitor.org/2013/04/19/canadianmining-company-east-asia-minerals-is-workingclosely-with-indonesian-government-officials-todestroy-acehs-forests/\#more-13762; East-Asia Minerals, Press Release: East Asia Minerals Announces Acquisition of 50\% of Carbon Conservation Pty Ltd, May3, 2011, http://www.marketwired.com/press-release/eastasia-minerals-announces-acquisition-of-50-ofcarbon-conservation-pty-ltd-tsx-venture-eas1509149. htm

${ }^{81}$ The Aceh Post, 2011, Hutan Aceh Dijadikan Aset Transaksi Saham, August 14, 2014. The Aceh Post, http://atjehpost.com/nanggroe/daerah/1896-hutanaceh-dijadikan-aset-transaksi-saham.htm
}

kawasan proyek Ulu Masen. Proyek pertambangan yang dikenal dengan Proyek Miwah merupakan area berkandungan emas tinggi berlokasi di dalam proyek REDD+ Ulu Masen. Hingga saat ini, EastAsia Minerals hanya mengantongi izin eksplorasi dan belum mendapatkan izin ekstraksi emas dari pemerintah.

Menyikapi sorotan dan kritikan keras mengenai hutan Aceh yang dijadikan agunan aset, CEO Dorjee Sun mengatakan perusahaannya tidak memiliki pilihan untuk bekerjasama dengan perusahaan yang justru destruktif karena adanya tekanan dari para banker dan investor. Mereka mempertanyakan di mana hasil keuntungan, uang dan keamanan investasi. $^{82}$ Dorjee menambahkan bahwa perusahaanya telah keliru dan meremehkan kesulitan pendanaan proyek REDD+ Ulu Masen. Selain itu, ia menekankan bahwa penjualan ini hanya mengorbankan sebagian kecil wilayah Ulu Masen demi kepentingan yang lebih besar, yakni melanjutkan program perlindungan bagi sisa wilayah yang jauh lebih luas.

Nampaknya, proyek REDD+ Ulu Masen yang hingga saat itu (2011) masih juga belum menghasilkan kredit karbon membuat bankir dan investor panik dan meminta uang mereka kembali. Uang yang telah dialokasikan untuk biaya operasional, 
teknis atau masuk kantong aktor-aktor lainnya tidak dapat dikembalikan lagi sehingga memaksa CC menjual saham serta hak eksklusifnya untuk mengembalikan dana investasi tersebut.

\section{f. Berhentinya Keterlibatan Pemda Aceh} Akibat Pergantian Kekuasaan kepada

\section{Zaini Abdullah}

Dalam pemilihan gubernur Aceh 2012, Gubernur Irwandi kalah dari Zaini Abdullah, juru bicara GAM di Swedia yang akhirnya kembali pulang ke Indonesia setelah perjanjian damai Helsinki. Bersama wakilnya, Muzakir Manaf, Gubernur Zaini Abdullah memiliki rencana yang lain terhadap hutan Aceh.

Ketika menyerukan penyetopan sementara proyek REDD+ Ulu Masen, sebelum sempat mencari alternatif lain pendanaan, secara politik Gubernur Irwandi telah kalah bersaing. Cita-cita Green Vision tidak lagi dapat dijual di masyarakat. Apalagi, proyek REDD+ Ulu Masen juga jarang terdengar di masyarakat umum. Gubernur Zaini Abdullah memiliki pandangan yang berbeda dengan pendahulunya mengenai pemanfaatan hutan Aceh.

Rencana spasial berubah total saat Gubernur Zaini Abdullah memegang pemerintahan. Pada 30 Oktober 2012, Abdullah menuliskan surat resmi kepada Kementerian Kehutanan mengajukan perubahan status hutan lindung menjadi hutan konsesi. $^{83}$ Dalam surat tersebut, Abdullah mengajukan lima blok hutan lindung seluas 21,311 ha untuk logging kayu. Tambahan tiga blok hutan lindung seluas 33,282 ha juga diajukan untuk diubah sebagai hutan produksi.

\section{Kesimpulan}

Implementasi REDD+ adalah sebuah proses mekanisme berjenjang dan multidimensional. Dengan demikian, proses ini melibatkan berbagai macam regulasi dan aktor di berbagai level yang memiliki agenda dan kepentingan masingmasing. Regulasi dan kepentingan tersebut harus dapat diharmonisasikan agar sebuah proyek REDD+ berjalan dengan baik dan menyasar tujuan hakiki REDD+, yakni reforestasi dan memberdayakan masyarakat lokal hutan. Harmonisasi regulasi dan kepentingan ini harus terjadi baik antar level, dari internasional ke subnasional serta antara pelaku baik mengenai sasaran pelaku hingga tujuan kolektif di antara aktor-aktor pada masing-masing level.

Dalam implementasi REDD+ di Ulu Masen ditemukan beberapa masalah yang menyebabkan gagalnya sinergi pengadopsian aturan atau regulasi serta pelaksanaan REDD+ dari level internasional hingga ke level sub-nasional.

\footnotetext{
${ }^{83}$ Greenomics Indonesia, 2013
} 
Masalah ini muncul karena dalam hubungan antar pelaku hingga pencapaian target serta tujuan kolektif disertai dengan pertentangan atau konflik kepentingan.

Pada level internasional, terjadi persoalan substansi dan aturan-aturan dalam UNFCCC yang terus menerus berubah pada level internasional, ketiadaan hukum tenurial yang memicu konflik, irelevansi mekanisme REDD+, inkonsistensi dan lemahnya audit CCBA. Kemudian, pada level nasional, masalah yang muncul adalah adanya UU yang pro deforestasi, permasalahan tenurial nasional yang belum beres, kontestasi antar lembaga pada pemerintahan pusat serta kontestasi antara lembaga pusat dan daerah (subnasional) yakni Pemerintah Daerah Aceh.

Kontestasi antara lembaga pusat meliputi hirarki UU yang carut marut, pembagian tugas dan tanggungjawab antara badan-badan pemerintah nasional yang tumpang tindih, tidak adanya kerangka hukum tinggi (UU) yang dikhususkan bagi pengaturan REDD+ secara formal. Kontestasi antara lembaga pusat dan daerah meliputi UU yang bertentangan bagi pembagian kewenangan pusat dan daerah mengatur sumber daya alam, UU Otonomi Khusus Aceh tahun 2006, perebutan tenurial antara pemerintah pusat dan Pemerintah Daerah Aceh.

Lalu pada level sub-nasional yang mana terdapat berbagai aktor yang memiliki fungsi dan peranan yang berbeda juga muncul permasalahan dalam melaksanakan kerangka REDD+. Permasalahan tersebut meliputi kontestasi di antara pengelola proyek yang menyebabkan tidak sinkronnya pelaksanaan proyek di lapangan serta seringnya terjadi saling lempar tanggungjawab, tidak adanya transparansi proyek, proses FPIC yang tidak berjalan, proyek REDD+ Ulu Masen menjadi lahan kepentingan bisnis perusahaan multinasional East-Asia Minerals dan Carbon Consertvation, terjadinya pergantian kepemimpinan Aceh kepada Gubernur Zaini Abdullah di tengah pelaksanaan proyek.

Dengan demikian, kemitraan litas sektor yang seharusnya terjadi tidak terjalin dalam implementasi REDD+. Apalagi aktor pada masing-masing level memiliki vested interests dan relasi power yang beragam sehingga proses REDD+ menjadi semakin rumit untuk diimplementasikan.Bisa jadi pada kasus di proyek lain tidak demikian. REDD+ pada akhirnya sangat bersifat hirarkikal.

Penelitian di Ulu Masen juga mempertegas bahwa mekanisme tata kelola global memang cenderung mengabaikan kearifan lokal. Aturan-aturan yang dibuat sangat teknikal dan mengabaikan masyarakat adat. Cara berpikir asing tidak melihat bahwa dalam pengelolaan hutan, 
masyarakat adat memiliki fungsi serta hukum tersendiri. Akibatnya, REDD+ membenturkan pemikiran asing ini dengan pemikiran lokal yang menyebabkan konflik baru. Konflik baru ini menyebabkan pemerintah negara berkembang harus berhadapan dengan masyarakat adat bukan sebagai mitra, melainkan penghambat berjalannya proyek.

Dengan demikian, implementasi REDD+ melalui mekanisme multi-level governance ternyata tidak berbeda dengan mekanisme tata kelola global pada umumnya. Perbedaan kekuatan negara, dari segi ekonomi dan pengaruh pada level pembuatan kebijakan tata kelola global

\section{DAFTAR PUSTAKA}

AFEP Annual Report, 2006.

Agung, Putra, 2010, Inisiasi kebijakan REDD di Indonesia: menunggu asa atau masalah, Jakarta, Indonesia, Intip Hutan.

Al-Fachri, et.al., 2009, Challenges of Forest Governance in Aceh, Eye on Aceh, 2-2.

Anderson, Sarah, John Cavanagh and Thea Lee, 1999, Ten Myths About Globalization. Nation, 12/06/99.

Angelsen, Arild and Wertz-Kanounnikoff, Sheila, 2009, Global and national REDD+ architecture: linking institutions and actions. In Arild Angelsen, M. Brockhaus, M. Kanninen, E. Sills, W. D. Sunderlin and S. WertzKanounnikoff, Realising REDD+: National Strategy and Policy Options (pp. 13-24), Bogor, Indonesia, Center for International Forestry Research. menyebabkan adanya gap insentif. Negaranegara yang tidak memiliki kekuatan ekonomi, seperti pada umumnya negaranegara berkembang, tidak berpengaruh dalam proses tata kelola dan kehilangan haknya untuk turut andil secara adil dan setara dalam penentuan mekanisme sebuah tata kelola global. Selain itu, "Think Global Act Local" yang menjadi motto utama MLG tidak menutup gap partisipasi, yang merujuk pada fakta bahwa kerjasama internasional masih didominasi oleh pemerintah negara dan mengesampingkan kelompok masyarakat sipil dalam pembuatan kebijakan dan pengambilan keputusan.

Angelsen, Arild, Brockhaus, M, Kanninen, M, Sills, E, Sunderlin, W. D. and WertzKanounnikoff, S, 2009, Realising REDD+: national strategy and policy options, Bogor, Indonesia, Center for International Forestry Research

Angelsen, Arild, et.al, 2013. Analysing REDD+: challenges and choices, Bogor, Indonesia, CIFOR.

Arma, Zulfikar, 22 April 2015, Personal Interview.

Arnold, Luke Lazarus, 2008, Deforestation In Decentralised Indonesia: What's Law Got To Do With It?, Law, Environment and Development Journal, 4(2), 77-100.

Astuti, Rini, 2013, Ekologi politik REDD+: kontestasi politik, modal dan pengetahuan, Yogyakarta, Wacana No.3

Bappenas. (2010). Draft Strategi REDD+ Nasional. April 15, 2015. 
http://forestclimatecenter.org/files/201009 -

03\%20Strategi\%20Nasional\%20REDD+ $\% 20$ DRAFT\%201\%20.pdf.

Basyah, Sabee, 22 April 2015, Personal Interview.

Biermann, Frank, et.al., 2009, Environmental Policy Integration And The Architecture Of Global Environmental Governance, International Environmental Agreements, 9, 351-369.

Brockhaus M., M. Di Gregorio and S. Mardiah, 2013, Governing the design of national REDD+: An analysis of the power of agency.

Brown, D, et.al, 2008, How do we achieve REDD co-benefits and avoid doing harm? In Arild Angelsen (Ed), Moving Ahead with REDD: Issues, Options and Implications (pp. 107-118), Bogor, Indonesia, CIFOR.

Bulkeley, Harriet and Newell, Peter, 2010, Governing climate change, London: Routledge.

Business Wire, 2010, Audit of How Sinarmas is Pulping the Planet,Melbourne: ITS Global.

Butler, R.A., L.P. Koh and J. Ghazoul, 2009, REDD In The Red: Palm Oil Could Undermine Carbon Payment Schemes. Conservation Letters, 2(2), 67-73.

Caplow, S., P. Jagger, K. Lawlor and E. Sills, 2011, Evaluating Land Use And Livelihood Impacts of Early Forest Carbon Projects: Lessons For Learning About REDD+, Environmental Sciency and Policy, 14(2), 152-167.

Carbon Planet. (December 4, 2009). The history of REDD policy. April, 22015. http://unfccc.int/files/methods/REDD/su bmissions/application/pdf/REDD_20091 216_carbon_planet_the_history_of_RE DDcarbon_plane.pdf

CBD. Conference of the Parties (COP). (2015, April 2). http://www.cbd.int/cop/.
Cerbu, GA., BM Swallow and DY Thompson, 2011), Locating REDD: A Global Survey And Analysis of REDD Readiness And Demonstration Activities, Environmental Science and Policy 14(2), 168-80.

CIFOR, 2010, REDD, Apakah itu?: pedoman cifor tentang hutan, perubahan iklim dan REDD, Bogor, Indonesia, CIFOR.

Clarke, Ross Andrew, 2010, Moving The REDD Debate From Theory To Practice: Lesson Learned From The Ulu Masen Project, Law, Environment and Development Journal, 6(1), 36-61.

Corbera, Esteve and Heike Schroeder, 2010, Governing and implementing REDD+, Environmental Science Policy, 14, 89230.

Cresswell, John W, 1994, Research design: qualitative and quantitative, London, Sage Publications.

Cronkleton, Peter, et.al., 2011), Supporting forest community in times of tenure uncertainty: participatory mapping experiences from bolivia and indonesia, Environmental Science and Policy, 14(2), 152-167.

Dingwerth, Klaus and Philipp Pattberg, 2006, Global Governance As A Perspective On World Politics, Global Governance, 12, 185-203.

Doherty, Emma and Heike Schroeder, 2011), Forest Tenure And Multi-Level Governance In Avoiding Deforestation Under REDD+, Global Environmental Politics, 11(4), 66-88.

Dunlop, Jane, 2009, REDD, Tenure And Local Communities: A Study From Aceh, Indonesia, International Development Law Organization.

East-Asia Minerals, Press Release: East Asia Minerals Announces Acquisition of $50 \%$ of Carbon Conservation Pty Ltd. May3, 2011. http://www.marketwired.com/pressrelease/east-asia-minerals-announcesacquisition-of-50-of-carbon- 
conservation-pty-ltd-tsx-venture-eas1509149.htm

Eklof, Goran, 2013, REDD Plus Or REDD "Light"? - Biodiversities, Communities And Forest Carbon Conservation, Swedish Society for Nature Conservation.

Estrada, M, 2011, Standards and methods available for estimating projectlevel REDD+ carbon benefits: reference guide for project developers. Bogor, Indonesia, CIFOR.

Esty, Daniel and Maria Ivanova, 2002, Revitalising Global Environmental Governance: A Function-Driven Approach, In Daniel Esty and Maria Ivanova (eds), 2002, Global Environmental Governance: Options and Opportunities, Yale School of Forestry and Enviromental Studies.

Eye on Aceh Interview with Retno Maryani, Indonesian Government Delegation to World Forestry Congress, Buenos Aires, Interviewed 24 Oktober 2009.

Fairbrass, Jenny and Andrew Jordan, 2005, Multi-level governance and environmental policy. In Ian Bache and Matthew Flinders (eds), Multi-level governance, New York, Oxford University Press.

FAO. (n.d). Finland-FAO forestry programme. April 8, 2015. http://www.fao.org/forestry/fma/76453 len

FAO. (n.d). REDD+ Partneship. April 11, 2015.

http://www.fao.org/partnerships/RED D-plus-partnership/en/

Fauna and Flora International, 2010, May 20, Ulu Masen REDD Project, FFI REDD+ Presentation.

Forest Carbon Partnership Facility. (n.d). About FCPF. April 3, 2015. https://www.forestcarbonpartnership.org $\underline{\text { about-fcpf-0 }}$

Forest People Programme. (2011). Aceh: Proyek Uji Coba REDD+ Ulu Masen.
Seri Briefing Hak-hak, Hutan dan Iklim. May 24, 2015. http://www.forestpeoples.org/sites/fpp/fi les/publication/2012/05/aceh-briefing-3edited.pdf.

Forsyth, Tim, 2009, Multilevel, multiaktor governance in REDD+. In Arild Angelsen, M. Brockhaus, M. Kanninen, E. Sills, W. D. Sunderlin and S. WertzKanounnikoff (eds), Realising REDD+: National Strategy and Policy Options, Bogor, Indonesia, Center for International Forestry Research.

Fry, Ben Palmer, 2011, Community Forest Monitoring In REDD+: The ' $M$ ' In $M R V$ ?, Environmental Science Policy, 14(2), 181-187.

Gebara, Maria Fernanda, et.al., 2014, REDD+ Policy Networks In Brazil: Constrains And Opportunities For Successful Policy Making, Ecology and Society, 19(3), 53.

George, S and I Bache, 2001, Politics In The European Union, Oxford, Oxford University Press.

Government of Norway. (2010). LOI between the Government of the Kingdom of Norway and the Government of the Republic of Indonesia on "Cooperation on reducing greenhouse gas emissions from deforestation and forest degradation. April 8, 2015 http://www.norway.or.id/PageFiles/4043 62/Letter_of_Intent_Norway_Indonesia_ 26_May_2010.pdf

Government of Norway. (n.d). Why a climate and forest initiative? April 3, 2015. https://www.regjeringen.no/en/id4/?404 \%3Bhttp\%3A\%2F\%2Fwww.regjeringen .no\%3A80\%2Fen\%2Fsystem\%2F404side\%2Fid2343711\%2F\%3F404\%3Bhtt p\%3A\%2F\%2Fwww.regjeringen.no\%3 A80\%2Fen $\% 2 \mathrm{Fdep} \% 2 \mathrm{Fmd} \% 2 \mathrm{FSelected}$ -topics $\% 2 \mathrm{Fclimate} \% 2 \mathrm{Fthe}$-governmentof-norways-international-\% $2 \mathrm{Fwhy}-\mathrm{a}$ climate-and-forestinitiative.html\%3Fid=54720/

Grainger, A and Michael Obersteiner, 2011, A Framework For Structuring The Global Forest Monitoring Landscape In The 
REDD-Plus Era, Environmental Science Policy, 14(2), 127-139.

Greenpeace (September 29, 2010). Apa itu REDD?. $\quad$ April, 2015. http://www.greenpeace.org/seasia/id/ca mpaigns/melindungi-hutan-alamterakhir/apa-itu-REDD/

Gupta, Joyeeta, Nicolien van der Grijp and Ono Kuik, 2013, Forests and REDD: Lesson For Institutional Design, New York, Routledge.

Hadi, Dedek, 24 April 2015, Personal Interview.

Hewson, Martin and Timothy J. Sinclair, 1999, The Emergence Of Global Governance Theory. In Martin Hewson and Timothy J. Sinclair (Eds). Approaches to global governance theory, New York, State University of Newyork.

Hix, Simon, 1998, Dimensions And Alignments In European Union Politics: Cognitive Constraints And Partisan Responses, Working Paper in European Studies, 1(3), 2-41.

Huber, Suzy. (2013). Indonesia Kerangka Hukum REDD+. April 4, 2015. http://theREDDdesk.org/sites/default/fil es/resources/pdf/2013/REDD_indonesia _bahasa_20_may.pdf

Huettner, Michael., Rick Leemans, Kasper Kok and Johannes Ebeling, 2009, A Comparison Of Baseline Methodologies For 'Reducing Emissions From Deforestation And Degradation', Carbon Balance and Management 4(1):4.

Husnan, et.al., 2013, Strategi dan Rencana Aksi Provinsi (SRAP) REDD+ Aceh.

Hyden, G., K. Mease, M. Foresti and V. Fritz, 2008, Governance Assessments For Local Stakeholders: What The World Governance Assessment Offers, Working Paper 287. Overseas Development Institute, London.

Ibrahim, 22 April 2015, Personal Interview.
Ibrahim, Anwar, 23 April 2015, Personal Interview.

Indrarto, Giorgio Budi, et,al, 2010, The Context of REDD+ in Indonesia, Bogor, Indonesia, CIFOR.

Indrarto, Giorgio Budi, et.al., 2012), The Context of REDD+ In Indonesia: Drivers, Agents, And Institutions, CIFOR Working Paper, 92, 1-115.

Intergovernmental Panel on Climate Change, 2007, Summary for Policymakers. In B. Metz, O.R. Davidson, P.R. Bosch, R. Dave, and L.A. Meyer (Eds). Climate Change 2007: Mitigation Contribution of Working Group III to the Fourth Assessment Report of the IPCC, New York, Cambridge University Press.

ITTO. (n.d). Techincal REDD+ Ghana. April 10 , 2015. http://www.itto.int/direct/topics/topics_p df.../topics_id $=2467 \&$ no $=3 \% 20$ or $\% 20 \mathrm{w}$ ww.itto.int $/$ news releases $/ \mathrm{id}=3222 \% 20 \mathrm{o}$ r\%20http://www.itto.int/files/itto_projec t_db_input/3046/Technical/REDD+\%20 in\%20Agricultural\%20Landscapes\%20i n\%20Ghana_Final\%20to\%20ITTO.pdf

Itubo, Anne F. and Giessen, Lukas. (2012). Discursive-multilevel REDD+ governance: political aktors' interests' on interplay of forests and climate change institutions in kenya. Institute for Forest Policy and Nature Conservation. http://www.kenyaforestservice.org/.

Karsenty, Alain, 2008, The Architecture Of Proposed REDD Schemes After Bali: Facing Critical Choice, International Forestry Review, 10(3), 443-457.

Karsenty, Alain, 2009, What the (Carbon) Market Cannot Do, CIRAD, 1.

Kasia, Rahmad, et.al., 2011, Penanganan Masalah Pembalakan Liar di Kawasan Ulu Masen Aceh, FFI Aceh Programme, November 2011.

Kementerian Kehutanan. (n.d). Dinamika REDD. $\quad$ April 20, 2015. http://www.REDDindonesia.org/index.php/regulasi/dinami ka-REDD 
Kementerian Kehutanan. (n.d). Tahapan IFCA. May 20, 2015. http://www.dephut.go.id/uploads/INFO RMASI/LITBANG/IFCA/Tahapan.htm

Knox, A, et.al., 2011, Land Tenure And Payment For Environmental Services: Challenges And Opportunities For REDD+, Land Tenure Journal, 2, 7-55.

Korhonen-Kurki, Kaisa, et.al., 2013, Multiple Levels And Multiple Challenges For Measurement, Reporting And Verification of REDD+, International Journal of the Commons, 7(2), 344-366.

Lang, Christopher. (2008, December 4). The Private Sektor and REDD: Turning Liabilities into Assets. REDD Monitor. February 16, 2015. http://www.REDDmonitor.org/2008/12/04/the-privatesektor-and-REDD-turning-liabilitiesintoassets.

Lang, Christopher. (2012, June 12). The story of REDD is just a lie," says Ulu Masen villager. REDD Monitor. November 1, 2014. http://www.REDDmonitor.org/2012/06/12/the-story-ofREDD-is-just-a-lie-says-ulu-masenvillager/

Lang, Christopher. (2013). Canadian Mining Company East Asia Minerals Is "Working Closely" With Indonesian Government Officials To Destroy Aceh's Forests. REDD-Monitor. April 24, $2015 . \quad$ http://www.reddmonitor.org/2013/04/19/canadianmining-company-east-asia-minerals-isworking-closely-with-indonesiangovernment-officials-to-destroy-acehsforests/\#more-13762

Lang, Christopher. (2013, March 8). Dorjee Sun, ulu masen and the burning season. REDD-Monitor. April 24, 2015. http://www.REDDmonitor.org/2013/03/08/dorjee-sun-ulumasen-and-the-burning-season/

Lang, Christopher. (2014, January 20). Interviews about Ulu Masen, Indonesia: A REDD-labelled Protected Area. REDD-Monitor. February 16, 2015. http://www.REDD- monitor.org/2010/01/20/interviewsabout-ulu-masen-indonesia-a-REDDlabelled-protected-area/

Lang, Christopher. 10 April 2015, Personal Interview.

Larson, Anne M. and Elena Petkova, 2011, An Intrduction To Forest Governance, People And REDD+ In Latin America: Obstacles And Opportunities, Forests, 2, 86-111.

Larson, Anne M., et.al., 2013, Land Tenure And REDD+: The Good, The Bad And The Ugly, Global Environmental Change, 23, 678-689.

Luttrell, Cecilia, 2011, Lessons For REDD+ From Measures To Control Illegal Logging In Indonesia, CIFOR Working Paper 74.

Lyster, Rosemary, Catherine MacKenzie and Constance McDermott, 2013, Law, Tropical Forests and Carbon: The Case of REDD+, New York, Cambridge University Press.

Mann, Tim and Muhammad Teguh Surya, 2009, REDD Wrong Path Pathetic Ecobusiness. Jakarta, Indonesia, Walhi

Mardiastuti, Ani, 2012, The role of $U N-R E D D$ in the development of REDD+ in Indonesia Volume III: Highlights of $R E D D+$ related projects in Indonesia, Jakarta, Indonesia, Indonesia Ministry of Forestry.

Marks, Gary and Liesbet Hooghe, 2005, Contrasting Visions of Multi-Level Governance. In Ian Bache and Matthew Flinders (Eds), 2005, Multi-level governance, New York, Oxford University Press.

Marks, Gary, 1993, Structural Policy and Multilevel Governance in the EU. In A. Cafruny and G. Rosenthal (eds.), 1993, The State of the European Community, New York: Lynne Rienner.

Marks, Gary, 2005, Multi-level Governance. In Ian Bache and Matthew Flinders (Eds), 2005, Multi-level governance, New York,Oxford University Press. 
Mayntz, Renate, 2004, Governance Im Modernen Staat. In Arthur Benz (ed), 2004, Governance - regieren in komplexen Regelsystemen: eine enfuhrung, Wiesbaden, VS Verlag fur Sozialwissenschaften

McCulloch, Lesley, 2010, Ulu Masen REDD Demonstration Project: The Challenges of Tackling Market Policy and Governances Failures that Underlie Deforestation and Forest Degradation, Intitute for Global Environmental Strategies.

Melviana, Armely., Diah Sulistiowati, dan Moekti Soejachmoen, 2007, Bumi Makin Panas: Ancaman Perubahan Iklim Di Indonesia, Jakarta, Yayasan Pelangi Indonesia.

Miller, M, M. Wilder and E. Knight, 2008, Climate Change And Forest: Emerging Policy And Market Opportunities. In C. Streck et.al. (Eds), 2008, Legal Issues And Contractual Solutions For Lulucf Projects Under The Clean Development Mechanism, London, Chatham House.

Mirwandah, 23 April 2015, Personal Interview.

Moeliono, M., C. Gallemore, L. Santoso, M. Brockhaus, and M. Di Gregorio, 2014, Information Networks And Power: Confronting The "Wicked Problem" Of REDD+ In Indonesia, Ecology and Society 19(2), 9 .

Najam, Adil, Mihaela Papa and Nadaa Taiyab, 2006, Global Environmental Governance: A Reform Agenda, Denmark, International Institute for Sustainable Development.

Nur Masripatin, 2010, Strategi REDD+ Indonesia.

Nurtjahjawilasa, et.al., 2013, Konsep REDD+ dan Implementasinya, Jakarta, Nature Conservancy Program.

O'Niles, John. (2007). It's Not Easy Being Green in Aceh, Indonesia. Forest Carbon Portal, October 25, 2007. http://www.forestcarbonportal.com/news /its-not-easy-being-green-aceh-indonesia
Pahl-Wostl, Claudia, 2009, A Conceptual Framework For Analysing Adaptive Capacity And Multi-Level Learning Processes In Resource Governance Regimes. Global Environmental Change, 19, 354-365.

Pemerintah Indonesia, n.d, UU No. 41/1999 tentang Kehutanan Artikel 1

Pemerintah Indonesia, n.d, Aturan UU No. 10/2004 mengenai Pembentukan Peraturan Perundang-undangan Artikel $7(1)$.

Pemerintah Indonesia, n.d, Aturan UU No. 12/2011 mengenai Pembentukan Peraturan Perundang-undangan Artikel $8(1)$.

Peskett, K, et.al., 2008, Making REDD Work for the Poor, London, UK, Overseas Development Institute and IUCN.

Piattoni, Simona, 2010, the Theory Of MultiLevel Governance: Conceptual, Empirical And Normative Challenges, New York, Oxford University Press.

Rathgeber, Theodor, 2009, Climate Change Violates Human Rights, Heinrich Boell Stiftung, 6.

REDD-Desk. (n.d). Ulu Masen Ecosystem Project. April 18, 2015. http://theREDDesk.org/countries/initiati ves/ulu-masen-ecosystem-project

Ridho, Dodhik dan M. Fadhil Hasan, 2012, Ekonomi Politik Kehutanan: Mengurai Mitos Dan Fakta Pengelolaan Hutan (2nd Ed), Jakarta, Indonesia, INDEF.

Risse, Thomas, 2011, Governance Without A State? Policies And Politics In Areas Of Limited Statehood, New York, Columbia University Press.

Rosenau, James N, 1992, Governance, Order And Change In World Politics, In James N. Rosenau and Ernst Otto-Czempiel (Eds), Governance without government, New York, Cambridge University Press.

Rosenau, James N, 1995, Governance In The Twenty-First Century, Global Governance, 1, pp. 13-43. 
Sapari, 23 April 2015, Personal Interview.

Satgas Nasional REDD+, 2012, Strategi Nasional dan Pendekatan Umum Penyusunan Strategi dan Rencana Aksi Provinsi.

Scheyvens, Henry and Agus Setyarso, 2010, Development Of A National REDD-Plus System In Indonesia, IGES Report.

Schlager, Edella and Elinor Ostrom, 1992, Property-Rights Regimes And Natural Resources, Land Economics, 68, 249262.

Siswanto, Wandojo dan Wahjudi Wardojo, 2006, Desentralisasi Sektor Kehutanan: Pengalaman Indonesia, Bogor, Indonesia, CIFOR.

Skutsch, M. and P.E. Van Laake, 2008, REDD As Multilevel Governance In theMaking. Energy and Environment, 19(6), 831-844.

Smith, J, et.al., 2007, Illegal Logging, Collusive Corruption and Fragmented Governments in Kalimantan, Indonesia, In L. Tacconi (Ed), 2007, Illegal Logging: Law Enforcement, Livelihoods and the Timber Trade, London, UK, Earthscan

Society of Indonesian Environmental Journalists. (2013). Satgas REDD+ dan kementerian kehutanan berebut kewenangan. May 20, 2015. http://www.siej.or.id/?w=article \&nid=45 0

Soedenberg, Susanne, 2006, Global Governance In Question: Empire, Class, And The New Common Sense In Managing Norh-South Relations, London, Pluto Press.

Soriano, Eleonor Baldo, et.al., 2010), Apa itu REDD? Sebuah Panduan Untuk Masyarakat Adat, Tebtebba, AIPP, FPP, IWGIA.

Speth, James Gustav and Peter M Haas, 2006, Global Environmental Governance, Washington, Island Press.
Springer, Jenny and Peter Bille Larsen, 2012, Community Tenure And REDD+, WWF Report June 2012.

Stern, Nicholas, 2006), Stern Review: The Economics of Climate Change, Cambridge, Cambridge University Press.

Streck, C., 2009, Rights And REDD+: Legal And Regulatory Considerations, In Arild Angelsen, M. Brockhaus, M. Kanninen, E. Sills, W. D. Sunderlin and S. WertzKanounnikoff, 2009, Realising REDD+: National Strategy and Policy Options, Bogor, Indonesia, CIFOR.

Sunderlin, William D., Hatcher, Jeffrey and Liddle, Megan. (2008). From exclusion to ownership? Challenges and opportunities in advancing forest tenure reform. The Rights and Resources Initiative. $\quad$ May 1, 2015. http://www.rightsandresources.org/docu ments/files/doc 736.pdf

The Aceh Post. (2011, May 6). Hutan aceh dijadikan aset transaksi saham. August 14, 2014. The Aceh Post. http://atjehpost.com/nanggroe/daerah/18 96-hutan-aceh-dijadikan-aset-transaksisaham.htm

The Provincial Government of Nangroe Aceh Darusslam, 2007, The Triple Benefit Project Design Note for CCBA Audit.

Thompson, Ian D., et.al., 2014, Biodiversity And Ecosystem Service: Lessons From Nature To Improve Management of Planted Forests For REDD-Plus, Biodivers Conserv, 23, 2613-2635.

UNFCCC. (2005, November 11). Submissions from Parties. Reducing emissions from deforestation in developing countries: approaches to stimulate action, 11 November 2005. Diakses pada 2 April 2015 melalui http://unfccc.int/resource/docs/2005/cop 11/eng/misc01.pdf

UNFCCC. (2009, December 19). COP 15 Copenhagen: report of the conference of the parties in its fifteenth session, held in Copenhagen from 7 to 19 December 2009. April 2, 2015. 
http://unfccc.int/resource/docs/2009/cop 15/eng/11a01.pdf.

UNFCCC. (2011, December 11). COP 17 Durban: report of the conference of the parties in its seventeenth session, held in Durban from 28 November to 11 December 2011. April 2, 2015. http://unfccc.int/resource/docs/2011/cop 17/eng/09a02.pdf

UNFCCC. (2013, November 23). COP 19 Warsaw: report of the conference of the parties in its nineteenth session, held in Warsaw from 11-23 November 2013. April 2, 2015. http://unfccc.int/resource/docs/2013/cop 19/eng/10a01.pdf.

UNFCCC. (2015, December 10). COP 16 Cancun: report of the conference of the parties in its sixteenth session, held in Cancun from 29 November to 10 December 2010. April 2, 2015. http://unfccc.int/resource/docs/2010/cop 16/eng/07a01.pdf

UNFCCC. (n.d). Australia: reducing emissions from deforestation and degradation in developing countries. April 10, 2015. http://unfccc.int/files/kyoto_protocol/ap plication/pdf/australia_lca_REDD.pdf

UN-REDD Programme, 2008, The UN-REDD Programme Strategy 2011-2015, Geneva, UN-REDD Secretariat.

UN-REDD. (n.d). Standard Joint Programme Document. April 16, 2015. http://www.un-

REDD.org/Portals/15/documents/events/ 20090309Panama/Documents/UNREDD\%20Indonesia\%20NJPD.pdf.

Weiss, Thomas G., 2013, Global Governance: Why? What? Whither?, Malden, MA, UK, Polity Press.

Wertz-Kanounnikoff, Sheila dan Arild Angelsen, 2010, Kerangka REDD+ Di Tingkat Global Dan Nasional: Memadukan Kelembagaan Dan Tindakan. In Arild Angelsen (ed), 2010, Mewujudkan REDD+: Strategi Nasional Dan Berbagai Pilihan Kebijakan (terj), Bogor, Indonesia, CIFOR.
Widiaryanto, Pungky, 2012, Does the Pressure of Population and Poverty Cause Deforestation?, Yogyakarta, Indonesia, JSP

Wiersema, Annecoos, 2014, Climate Change, Forests And International Law: REDD's Descent Into Irrelevance, Vanderbilt Journal of International Law, 47(1).

Wiersema, Annecoos. (2014). Climate Change, Forests and International Law: REDD's Descent into Irrelevance. Vanderbilt Journal of International Law, 47(1). April 19, 2015. http://www.vanderbilt.edu/jotl/2014/03/c limate-change-forests-and-internationallaw-REDD\%E2\%80\%99s-descent-intoirrelevance/

Wollenberg, Eva, et.al., 2009, Antara Negara dan Masyarakat: Desentralisasi di Indonesia. In Moira Moeliono, et.al (Eds), 2009, Desentralisasi Tata Kelola Hutan: Politik, Ekonomi dan Perjuangan untuk Menguasai Hutan di Kalimantan, Indonesia, Bogor, Indonesia, CIFOR

Yasman, Irsyal, et.al., 2013, Peran Pengelolaan Hutan Produksi Alam Dalam Perubahan Iklim (REDD+ Pengelolaan Hutan Lestari Dan RIL-C). Jakarta, Indonesia, Natural Resources Development Center.

Yasmi, Y., L. Kelley, D. Murdiyarso and T. Patel, 2012, The Struggle Over Asia's Forests: An Overview Of Forest Conflict And Potential Implications For REDD+, International Forestry Review, 14(1), 99-109.

Young, Oran and Heike Schroeder, 2008, Institutions and Environmental Change, Cambridge, The MIT Press.

Zurn, M, 2010, Global Governance As MultiLevel Governance, In H. Enderlein, S. Walti, and M. Zurn (eds), 2010, Handbook on Multi-Level Governance, Cheltenham, Edward Elgar 